\title{
Decolonial conservation: establishing Indigenous Protected Areas for future generations in the face of extractive capitalism
}

\author{
Megan Youdelis a 1 \\ Justine Townsend ${ }^{\text {a }}$ \\ Jonaki Bhattacharyya b, c \\ Faisal Moola ${ }^{a}$ \\ J.B. Fobister ${ }^{d}$ \\ a University of Guelph, Canada \\ b Dasiqox-Nexwagwez?an, Tsilhqot'in Territory \\ c University of Victoria, Canada \\ ${ }^{d}$ Grassy Narrows First Nation, Treaty 3 Area \\ refereed preprint awaiting pp.
}

\begin{abstract}
Extractive capitalism has long been the driving force of settler colonialism in Canada, and continues to threaten the sovereignty, lands and waters of Indigenous nations across the country. While ostensibly counterposed to extractivism, state-led conservation has similarly served to alienate Indigenous peoples from their territories, often for capitalist gain. Recognizing the inadequacy of the colonial-capitalist conservation paradigm to redress the biodiversity crisis, scholars in political ecology increasingly call for radical, convivial alternatives rooted in equity and justice. Indigenous Protected and Conserved Areas (IPCAs) are one such alternative, representing a paradigm shift from colonial to Indigenous-led conservation that reinvigorates Indigenous knowledge and governance systems. Since the Indigenous Circle of Experts finalized a report in 2018 on how IPCAs could contribute to Canada's conservation targets and reconciliation efforts, an increasing number of Indigenous stewardship initiatives across the country have been declared as IPCAs. These initiatives are assertions of Indigenous sovereignty, inherent rights, and responsibilities to their territories, as well as movements to rejuvenate biocultural conservation. Although Canada is supporting IPCAs through certain initiatives, the country's extractivist development model along with jurisdictional inconsistencies are undermining the establishment and long-term viability of many IPCAs. This paper explores two instances where Indigenous governments have established, or are establishing, IPCAs as novel strategies for land and water protection within long histories of resistance to colonial-capitalist exploitation. We argue that there is a paradoxical tension in Canadian conservation whereby Indigenous-led conservation is promoted in theory, while being

\footnotetext{
${ }^{1}$ Dr. Megan Youdelis (Post-doc), Justine Townsend (PhD student), and Dr. Faisal Moola (Associate Professor), Department of Geography, Environment and Geomatics, University of Guelph, Canada. Email: megan.youdelis "at" uoguelph.ca. Dr. Jonaki Bhattacharyya, Dasiqox-Nexwagwez?an and School of Environmental Studies, University of Victoria, Canada. J.B. Fobister, Grassy Narrows First Nation, Land Protection Team, Treaty 3 Area. Acknowledgements: The authors gratefully acknowledge the contributions of former Chiefs Russell Myers Ross (Yunesitin Government) and Marilyn Baptiste (Xeni Gwet'in First Nation) who reviewed drafts and whose insight and expertise were instrumental to telling the story of Dasiqox-Nexwagwez?an as well as the political analysis. We also acknowledge the perseverance and vision of Grassy Narrows First Nation and the Tsilhqot'in Nation, including all of the Elders and community members, in protecting their lands and waters for future generations. Thank you also to the referees whose insights strengthened the article. This is the xx article in Dan Brockington, Esteve Corbera and Sara Maestre (eds.). 2021. "The challenges of decolonizing conservation", Special Section of the Journal of Political Ecology 28.
} 
undermined in practice. IPCAs offer glimpses of productive, alternative sustainabilities that move away from the colonial-capitalist paradigm, but are being challenged by governments and industries that still fail to respect Indigenous jurisdiction.

Keywords: Conservation; Indigenous Protected and Conserved Areas (IPCAs); extractive industry; convivial conservation; Canada

\section{Resumé}

Le capitalisme extractif a longtemps été la force motrice du colonialisme de peuplement au Canada, et continue de menacer la souveraineté, les terres et les eaux des nations Autochtones à travers le pays. Bien qu'elle soit ostensiblement opposée à l'extractivisme, la conservation dirigée par l'État a également servi à aliéner les peuples Autochtones de leurs territoires, souvent pour le profit capitaliste. Reconnaissant l'insuffisance du paradigme de conservation colonial-capitaliste pour remédier à la crise de la biodiversité, les chercheurs en écologie politique demandent de plus en plus des alternatives radicales et conviviales enracinées dans l'équité et la justice. Les Aires Protégées et Conservées Autochtones (IPCAs, pour son acronyme en anglais) sont l'une de ces alternatives, représentant un changement de paradigme de la conservation coloniale à la conservation dirigée par les Autochtones qui revigore les connaissances et les systèmes de gouvernance Autochtones. Depuis que le Cercle d'Experts Autochtones a finalisé un rapport en 2018 sur la façon dont les IPCAs pourraient contribuer aux objectifs de conservation du Canada et aux efforts de réconciliation, un nombre croissant d'initiatives d'intendance Autochtone à travers le pays ont été déclarées IPCAs. Ces initiatives sont des affirmations de la souveraineté Autochtone, leurs droits inhérents et leurs responsabilités envers leurs territoires, ainsi que des mouvements pour rajeunir la conservation bioculturelle. Bien que le Canada appuie les IPCAs par le biais de certaines initiatives, le modèle de développement extractiviste du pays ainsi que les incohérences juridictionnelles compromettent l'établissement et la viabilité à long terme de nombreuses IPCAs. Cet article explore deux cas où les gouvernements Autochtones ont établi, ou sont en train d'établir, des IPCAs en tant que nouvelles stratégies de protection des terres et de l'eau dans le cadre d'une longue histoire de résistance à l'exploitation coloniale-capitaliste. Nous soutenons qu'il existe une tension paradoxale dans la conservation canadienne selon laquelle la conservation dirigée par les Autochtones est promue en théorie, alors qu'elle est minée dans la pratique. Les IPCAs offrent des aperçus de durabilités productives et alternatives qui s'éloignent du paradigme colonial-capitaliste, mais sont minées par les gouvernements et les industries qui ne respectent toujours pas la juridiction Autochtone.

Mots-clés: Préservation; Aires protégées et conservées autochtones; industrie extractive; préservation conviviale; Canada

\section{Resumen}

El capitalismo extractivista ha sido durante mucho tiempo la fuerza impulsora del colonialismo en Canadá por parte de los colonos y continúa amenazando la soberanía, las tierras y las aguas de las naciones indígenas en todo el país. Aunque ostensiblemente se opone al extractivismo, la conservación dirigida por el estado ha alienado también a los pueblos indígenas de sus territorios, a menudo en beneficio del capitalismo. Reconociendo la insuficiencia del paradigma de conservación colonial-capitalista para corregir la crisis de la biodiversidad, la ecología política promueve alternativas radicales enraizadas en la equidad y la justicia. Las Áreas de Protección y Conservación Indígenas (IPCAs, por sus siglas en inglés) son una de esas alternativas, y representan un cambio de paradigma de la conservación colonial porque están lideradas por indígenas y pretenden revitalizar el conocimiento indígena y los sistemas de gobernanza. Desde que el Círculo de Expertos Indígenas finalizó un informe en 2018 sobre cómo las IPCAs podrían contribuir a los objetivos de conservación y los esfuerzos de reconciliación de Canadá, un número cada vez mayor de iniciativas de administración indígena en todo el país han sido declaradas como IPCAs. Estas iniciativas son afirmaciones de soberanía indígena, derechos inherentes y responsabilidades hacia sus territorios, así como movimientos para rejuvenecer la conservación biocultural. Aunque Canadá está apoyando a las IPCAs, el modelo de desarrollo extractivista del país, junto con las inconsistencias jurisdiccionales, están socavando el establecimiento y la viabilidad a largo plazo de muchas de éstas. Este artículo explora dos instancias en las que los gobiernos indígenas han establecido, o están estableciendo, las IPCAs como estrategias novedosas para la protección de la tierra y el agua dentro de una larga historia de resistencia a la explotación colonial-capitalista. Argumentamos que existe una tensión paradójica en la conservación canadiense por la cual la conservación liderada por indígenas se promueve en teoría, mientras que se socava en la práctica. Las IPCAs ofrecen destellos de una sustentabilidad 
alternativa que se aleja del paradigma colonial-capitalista, pero están siendo desafiadas por gobiernos e industrias que aún no respetan la jurisdicción indígena.

Palabras clave: Conservación, Áreas de Protección y Conservación Indígenas; extractivismo; conservación amable; Canadá

\section{Introduction}

Given that conventional approaches to conservation (both protectionist and market-based) have often dispossessed Indigenous peoples from their territories (Brockington and Igoe, 2006; Holmes and Cavanagh, 2016; Lunstrum, 2016; Stevens, 2014), while largely failing to stave off severe biodiversity decline globally (IPBES, 2019; Fletcher et al. 2020), scholars in political ecology are increasingly calling for a "conservation revolution" (Büscher and Fletcher, 2020). Büscher and Fletcher (2020) term this revolution "convivial conservation", which is "a vision, a politics and a set of governance principles that... proposes a post-capitalist approach to conservation that promotes radical equity, structural transformation and environmental justice" (Büscher and Fletcher, 2019: 283). Conviviality requires transcending the separation between humans and non-human nature imposed by conventional protected areas and moving beyond conservation politics that are premised on and reproduce capitalist relations of production, consumption and accumulation (Büscher and Fletcher, 2020).

While Büscher and Fletcher (2020) focus primarily on post-capitalist environmental politics, they recognize the necessity for decolonial conservation and acknowledge that their vision for alternative sustainabilities is not "wholly new" (p. 159), pointing to Indigenous-led stewardship initiatives that have long embodied conviviality (ICCA Consortium, n.d.). Indeed, colonialism and capitalism are inseparable phenomena (Coulthard, 2014; Estes, 2019), and the roots of the Anthropocene crisis arguably trace back to European colonialism and Indigenous dispossession (Davis and Todd, 2017; Lewis and Maslin, 2015, 2017). Addressing the roots of this crisis, Indigenous-led conservation thus represents a fecund decolonial alternative to conventional state, non-governmental and private-led approaches to protected areas, and helps "maintain the conditions of possibility for a future decolonial and anti-capitalist social transformation" (Bernauer and Roth, 2021: 216).

In Canada, although Indigenous peoples have been stewarding their territories for millennia, there has been a recent surge in Indigenous governments and nations declaring Indigenous Protected and Conserved $\operatorname{Areas}^{2}$ (IPCAs) in their territories. IPCAs are "Indigenous-led; they represent a long-term commitment to conservation; and they elevate Indigenous rights and responsibilities" (ICE, 2018: 5). Conventional conservation is generally rooted in a worldview which delineates a separation of humans and nature, constructing conservation as something that happens 'out there' and not in the places where people actually live (Cronon, 1996). In contrast, IPCAs are managed in accordance with Indigenous laws, which are usually informed by or founded on 'Natural Law': a term referring to worldviews in which humans have responsibilities to uphold reciprocal relationships with other species and play a vital role in the functioning of healthy ecosystems (Borrows, 2010; McDermott and Wilson, 2010; McGregor, 2018). As IPCAs are managed in accordance with Indigenous legal and knowledge systems, they are designed to facilitate not only ecological conservation, but also sustainable livelihoods and self-determination, cultural and language revitalization, and the maintenance of Indigenous knowledge systems (Carroll, 2014; ICE, 2018; Murray and King, 2012). As an expression of Indigenous governance, IPCAs reflect a conservation agenda that is not only rooted in social and environmental justice, but also highly effective at protecting biodiversity while reducing park-people conflicts (Artelle et al. 2019).

\footnotetext{
${ }^{2}$ IPCAs have many different names including Indigenous Protected Areas (IPAs), Indigenous Cultural Landscapes, Tribal Parks, Indigenous conserved areas, Indigenous Community Conserved Areas (ICCAs), territories of life, country, sacred natural sites, and many more (many of which are not in the English language) (ICE, 2018; ICCA Consortium, n.d.; Tran et al., 2020). IPCA is the general term that the Indigenous Circle of Experts used in their final report that includes all of these expressions of Indigenous-led conservation (ICE, 2018).
} 
Canadian federal, provincial, and territorial (Crown) governments have shown a growing commitment to Indigenous-led conservation. In 2017, the federal government commissioned the Indigenous Circle of Experts (ICE) to advise Canada on how IPCAs can contribute to the country's global biodiversity conservation commitments in the spirit of reconciliation with Indigenous peoples. While ICE noted that reconciliation can be interpreted widely, they defined it as a "healing process for restoring relationships: first, between the Crown and Indigenous Peoples....and second, between all people (Indigenous and non-Indigenous) and the lands" (2018: 7). ICE delivered their landmark report in March 2018, with 28 recommendations for supporting and expanding IPCAs to meet Canada's international targets of conserving $17 \%$ of terrestrial areas and inland waters by December 2020 (ICE, 2018). Arising from a related process, the National Advisory Panel (2018) report recognized the importance of Indigenous involvement in protected area establishment. In the same year, Canada announced a CAN\$500 million-dollar (US\$395.5m) Nature Fund which was matched by conservation partners to raise CAN\$1 billion (US\$790.8m) for domestic conservation efforts, with up to $\$ 175$ million (US\$138m) available through the Target 1 Challenge Fund program for the establishment of new protected areas including IPCAs (Government of Canada, 2018).

But although the government of Canada is supporting IPCAs through certain initiatives, the country's extractivist development model (Bernauer and Roth, 2021; Peyton and Franks, 2016) along with jurisdictional inconsistencies (Willow, 2012) are undermining the establishment and long-term viability of many IPCAs. As it stands, the traditional territories and proposed or declared IPCAs of many Indigenous nations are overlain with various tenures (e.g. mineral, forestry, oil and gas, hydroelectric, etc.) that threaten their ecological and cultural viability. In this article we explore two prominent cases where ongoing pressure from extractive industries (facilitated by Crown government permitting and policies) is undermining efforts by Indigenous governments to establish and secure IPCAs: Nexwagwez?an-Dasiqox ${ }^{3}$ Tribal Park (Dasiqox-Nexwagwez?an) in B.C. (non-Treatied territory) and Grassy Narrows Indigenous Sovereignty and Protected Area (ISPA) in Ontario (Treaty 3 territory) ${ }^{4}$. All of the First Nations involved - Xeni Gwet'in First Nations Government, Yunesit'in Government, and Tsilhqot'in National Government in Dasiqox-Nexwagwez?an and Asubpeeschoseewagong First Nation in Grassy Narrows ISPA - have been engaged in decades-long struggles to protect the vitality of their lands and waters from extractive industries ${ }^{5}$ (Willow, 2012; Townsend et al., 2019). All of these First Nations have fought expensive battles in court and have engaged in on-the-ground direct action in the form of blockades to protect their constitutionally enshrined rights, a travesty in a country that has introduced legislation to support the full implementation of the United Nations Declaration on the Rights of Indigenous Peoples (UNDRIP), with its principle of free, prior and informed consent (Government of Canada 2020; UNDRIP 2008).

Taking a political ecology approach (Middleton, 2015; Neumann, 2005; Schulz, 2017), attentive to how political economy and colonial power relations shape biocultural outcomes, we situate these cases within the wider context of Indigenous struggles around land defense and territorial sovereignty as well as within broader conversations around theorizing and enacting a conservation revolution (Büscher and Fletcher, 2020; Fletcher et al., 2020). We argue that there is a paradoxical tension in the Canadian conservation sector whereby Indigenous-led conservation is supported in theory, but actively undermined in practice. While Crown

\footnotetext{
${ }^{3}$ Pronounced "Da-see-ko."

4 'Non-treatied territory' refers to the fact that the Indigenous Nations with ancestral and ongoing ties to their territory did not sign a treaty (i.e. an early Peace and Friendship, numbered, or modern-day treaty) with the Crown. Regardless of the existence of treaties, "Aboriginal" (i.e. First Nations, Métis, and Inuit) rights, as well as treaty rights are acknowledged and affirmed in the Canadian constitution. Indigenous Nations who signed treaties possess Aboriginal rights as well as treaty rights as defined by the terms of their particular treaty. Between 1871-1921 eleven numbered treaties covering most of Canada were signed between the British Crown and many Indigenous Nations (following on earlier "Peace and Friendship Treaties" beginning in 1701). Treaty 8 is the only numbered treaty that partially extends into what is now northeast B.C. and 14 Douglas Treaties cover Vancouver Island. A treaty table with B.C. and federal representatives was established to support the negotiation of modern-day treaties with the first implemented in 2000.

${ }^{5}$ We use the preferred naming conventions of the Indigenous governments, nations, and communities discussed in this article.
} 
agencies are increasingly partnering with Indigenous governments on IPCA establishment on the one hand (Government of Canada, 2018), federal and provincial agencies continue to allow Indigenous lands and waters —including those within declared and proposed IPCAs - to be pillaged by non-Indigenous industries, and many Crown government agencies are hesitant to respect Indigenous jurisdiction or are passively resistant to working out new ways to do so. For many nations, including Grassy Narrows and Tsilhqot'in, IPCAs are a novel and supplementary strategy for territorial protection within a long history of sustained resistance to colonial-capitalist exploitation. If adequately recognized and supported by Crown governments and settler society, IPCAs have the potential to facilitate reconciliation through conservation and model alternative sustainabilities both within and beyond protected areas, thereby contributing to the conservation revolution (Büscher and Fletcher, 2020).

\section{Colonialism, conservation, and extractive capital}

Indigenous peoples in Canada have been fighting the colonial-capitalist takeover of their lands and waters since contact (Coburn and LaRoque, 2015; Coulthard, 2014; Manuel and Grand Chief Derrickson, 2015; Spice, 2018). Current struggles consistent with the broader Land Back movement (Yellowhead Institute, 2019) remind us that colonialism is not an event that can be relegated to the past, but is an ongoing structure of dispossession that shapes our colonial present. Examples include Wet'suwet'en Hereditary Chiefs' fight to protect their territory from the Coastal GasLink pipeline (Bellrichard, 2019; Unist'ot'en, 2017), the Secwepemc fight against the Trans Mountain Pipeline Expansion (Tiny House Warriors, 2020), the Six Nations of the Grand Rapids' struggle to defend their territory from housing development (Barrera, 2020), and the Sipekne'katik Nation's fight to exercise their treaty rights in their lobster fishery (Moore, 2020). "Settler colonialism is territorially acquisitive in perpetuity" (Coulthard, 2014: 152), as it continues to alienate Indigenous peoples from their traditional territories such that the land remains open for capitalist development (Coulthard, 2014; Tuck and Yang, 2012).

In Canada, both extractive industry and state-led conservation have facilitated this alienation (Bernauer and Roth, 2021; Binnema and Niemi, 2006; Youdelis, 2016). Bernauer and Roth (2021) note that "Canada's imperialist project, both at home and abroad, is and always has been extractivist", meaning that "development programs...look to capitalist extraction as a primary driver of national development" (p. 210; see also Peyton and Franks, 2015). The fur trade aside, Canada's extractive economies required and proceeded through the dispossession of Indigenous peoples through a multitude of strategies, ranging from treaty negotiations, to direct military invasion, to the abduction of children for residential schooling, among others (Barkwell, 2005; Bernauer and Roth, 2021; Coulthard, 2014; Daschuk, 2013; Miller, 2009; Pasternak et al., 2013; TRC, 2015; Watkins, 1977; Zalik, 2011). While strategies since the 1960s rely more heavily on persuasion and manufacturing consent (Couldhard, 2014; Bernauer and Roth, 2021), extractive industry continues to undergird the very structure of settler colonialism as it undermines the sovereignty, lands and waters of many nations across the country (Yellowhead Institute, 2019).

Although conservation and extractive capital are ostensibly strange bedfellows, a growing number of scholars in political ecology are illuminating the "global trend of intensifying and deepening relationships between extractive companies and biodiversity conservation organizations" (Enns et al., 2019: 967). Fletcher and Büscher (2020) argue that "the expansion of extractive industries driven by dynamics of capital accumulation" (p. 2) is the first of the two main root causes of global biodiversity loss. This notwithstanding, extraction and conservation activities increasingly occur in close proximity to one another as it is becoming more common for conservation to be carried out through partnerships between extractive capital and conservation organizations (Enns et al., 2019). Over three quarters of all resource exploration or extraction globally overlaps with conservation areas, and one third of mining activities occur in ecologically sensitive areas, with one quarter taking place within a $10 \mathrm{~km}$ radius of areas classified as 'strictly protected' by the International Union for the Conservation of Nature (WRI, 2003). Importantly, both sectors commodify nature for exchange (be that through tourism or resource development), and thus their activities employ complimentary logics and technologies of dispossession (Büscher and Davidov, 2013; Norris, 2017; Seagle, 2012). 
Like extractive capital, state-led conservation has historically been a tool of colonial territorialization. Protected areas have served to expand the territorial control of colonial and modern states by displacing Indigenous peoples from their territories, most often for capitalist gain (Agrawal and Redford, 2009; Bernauer and Roth, 2021; Büscher and Davidov, 2013; Chatty and Colchester, 2002; Dowie, 2009; Youdelis, 2016; West et al., 2006). In Canada, as elsewhere (Lunstrum, 2016; Neumann, 1998; Vandergeest and Peluso, 1995), Indigenous peoples were alienated, and at times forcefully removed in the name of "conservation", from the territories they had long managed sustainably (Binnema and Niemi, 2006; MacLaren, 2007; Sandlos, 2008). Profit generation was one of the primary motivating factors for the early creation of the Canadian park system. The first parks were established as tourist destinations for the well-off clientele of the Canadian Pacific Railway corporation, and a few parks supported mining for a time (Bella 1987; Campbell, 2011). Governments restricting access to or evicting Indigenous peoples from their territories thus served to produce an artificial image of pristine wilderness marketed to tourists and sport hunters (Binnema and Niemi, 2006; Loo, 2001; Sandlos, 2008). Indigenous livelihoods and land stewardship practices were eschewed as antithetical to conservation in favour of tourism. In many ways, commercial tourism continues to be upheld as more "conservation-friendly" than Indigenous livelihoods and stewardship practices in the management policies of older state-led parks (Youdelis et al., 2020).

More recently, in state-led protected areas (e.g. those established since the 1970s) Indigenous peoples tend to have more opportunities for shared governance, as well as rights to access and carry out traditional livelihood activities (Bernauer and Roth, 2021; Sandlos, 2014; Youdelis et al., 2020), although many maintain colonial power dynamics and marginalize Indigenous knowledge systems (Nadasdy, 2005). For example, certain Indigenous governments have partnered with Parks Canada in order to secure harvesting rights within protected areas in their territories in the face of the dominance of extractive capital (e.g. Tallurutiup Tariunga in Nunavut, among others). However, Bernauer and Roth (2021) argue that in the absence of a wellarticulated political alternative to extractivism in Canada's northern territories, these new protected areas can act as spatial fixes which can be used to further justify the expansion of extractive capital outside of park boundaries (Enns et al, 2019), and remain vulnerable to the effects of extraction.

Not only has the colonial-capitalist approach to conservation negatively impacted Indigenous cultures and identities, entrenching poverty and contributing to social dislocation (Coulthard, 2014; Snow, 1977), it has produced dubious ecological results. In 2013, the Commissioner of the Environment and Sustainable Development reported that there were significant gaps in Parks Canada's commitments and their achievements, noting that less than half of all parks were considered to be in good condition, and the $43 \%$ of parks assessed to be in fair condition were showing a decline in ecosystem health (Office of the Auditor General of Canada, 2013). Parks Canada and several non-governmental conservation organizations have also noted that the ecosystems of state-led parks are stressed and threatened by development pressures including extractive industries (CPAWS, 2012; Parks Canada, 2019). For example, according to the International Union for the Conservation of Nature (IUCN), Wood Buffalo, Canada's largest national park, is among the most threatened World Heritage Sites in North America due to hydroelectric dams and oilsands development (IUCN, 2020; Weber, 2017). UNESCO has called for a buffer zone around Gros Morne National Park, another World Heritage Site threatened by hydraulic fracking (CBC, 2014), and in 2014, the Province of British Columbia (B.C.) passed Bill F4, opening provincial parks to mining exploration (Linnitt, 2014). More broadly, global studies show that for a number of reasons, including island biogeography and external development pressures, fortress-style conservation areas have been experiencing detrimental ecological impacts, such as loss of biodiversity and increased deforestation (Armitage, 2002; Neumann, 1992; Roth, 2008; West, 2006). While state-led parks have in many ways acted as bulwarks against capitalism's environmental externalities, they are increasingly being subjected to, damaged and threatened by the same colonial-capitalist policies and practices that are decimating areas outside of park boundaries, affecting primarily Indigenous communities and other racialized minorities.

Although moving in the right direction, state-led approaches to reconciliation —including granting incremental rights to Indigenous peoples in conservation areas or entering into co-management arrangementshave been critiqued for maintaining colonial relations of power, as the Crown, holding statutory power, is presumed to possess the authority to either bestow or disallow rights to Indigenous peoples (Mabee and 
Hoberg, 2006; Sandlos, 2014; Youdelis, 2016). One party holding veto power over another does not allow for true nation-to-nation, government-to-government, or Inuit-to-Crown relationships, and Indigenous peoples' roles in environmental governance become, for the most part, advisory (ICE, 2018). By contrast, Indigenousled conservation provides an opportunity to surmount the colonial politics of 'recognition' (Coulthard, 2014) as Indigenous peoples assert their inherent rights to exercise their responsibilities to their lands and waters as sovereign Indigenous peoples. ${ }^{6}$

Within the context of struggles around territorial sovereignty, self-determination, land protection, and treaty $^{7}$ and Aboriginal ${ }^{8}$ rights and title, an increasing number of Indigenous governments and nations have been mobilizing IPCAs to assert alternative visions for a conservation paradigm in line with Indigenous rights and responsibilities, economies, and worldviews, often in direct response to threats from resource extraction (Mulrennan et al., 2012; Tran et al., 2020). Motivations for IPCA establishment are numerous and varied including protecting cultural and spiritual values, revitalizing Indigenous livelihoods and economies, supporting language rejuvenation, facilitating intergenerational knowledge transfer, asserting self-determination and sovereignty, and protecting the lands and waters for generations into the future, among others. Tran et al. (2020) found that "many of the underlying socio-cultural and political reasons behind establishing IPCA initiatives were to improve conditions for peoples and territories that have been (and continue to be) severely impacted by colonial practices and values" (p. 5).

While Canadian conservation authorities tend to prioritize large areas of intact ecosystems for protected area establishment, not all IPCAs are established in pristine areas. At times they are established in places that have been heavily degraded by extraction, pollution or development, such as Grassy Narrows ISPA and K'ih Tsaa?dze Tribal Park in B.C. In such places, IPCAs focus on restoration, healing, and reconnection to the land and water. Degraded or not, Indigenous governments and nations often declare IPCAs in response to extractive and development pressures to assert an alternate vision for the land, water, and cultural survival (e.g. in addition to Grassy Narrows ISPA and Dasiqox-Nexwagwez?an, also Kitasoo/Xai'xais Indigenous Protected Areas, Qat'muk Tribal Park, and Tla-o-qui-aht Tribal Parks in B.C.; Thaidene Nëné and Edéhzhíe Protected Area in the Northwest Territories, among others). Here, IPCAs are assertions of the authority of Indigenous peoples to exercise their rights and title and to protect their territories from unwanted development and secure biocultural continuity.

Grassy Narrows ISPA and Dasiqox-Nexwagwez?an are representative of IPCAs mobilized in the context of long held struggles against extractive industry. Grassy Narrows First Nation's territory has been contaminated with mercury since the 1960s, when a nearby pulp and paper mill spilled the toxin into their river system. Additionally, they have been fighting against the clearcutting of significant areas within their Traditional Land Use Area since the 1990s. The Xeni Gwet'in First Nations Government, the Yunesit'in Government, and the Tsilhqot'in National Government have been resisting a proposed open-pit copper and gold mine in their territory for approximately 30 years while extensive logging has also heavily impacted their territories. In what follows, we explore these nations' motivations for mobilizing IPCAs in their ongoing struggles over land, water, and jurisdiction, and the major challenges they face in realizing their visions for their territories.

\footnotetext{
${ }^{6}$ Inherent rights are intrinsic and exist regardless of processes or institutions of recognition. In this sense, they are distinct from rights acquired through treaties and/or Crown legal recognition. Inherent rights predate colonization and cannot be extinguished by colonial governments (Norman 2017; von de Porten, McGregor and Silver 2016).

${ }^{7}$ Treaty rights refer to rights that flow from treaties signed between Indigenous Nations and Crown governments. Treaty rights include both historic and modern treaties and differ from treaty to treaty.

${ }^{8}$ Section 35 of the Constitution Act, 1982 recognizes "existing Aboriginal and Treaty rights." Although left ambiguous in the Constitution, Aboriginal rights have been defined over time through many Supreme Court cases, such as R v. Calder, R v. Sparrow, and R v. Delgamuukw. In general, Aboriginal rights are collective rights and specific to distinct Indigenous peoples. Aboriginal rights can include the right to subsist on the land through activities such as hunting, fishing, and trapping, as well as the right to self-determination and self-government, and a right to modest livelihoods through commercial markets. These rights are inherent to Indigenous peoples and flow from their continued occupation of a particular territory (Asch, 1984; Thom, 2001).
} 


\section{Methods}

This article integrates collaborative research and the direct experience of authors and Indigenous knowledge holders. Research included a review of relevant academic and gray literature, semi-structured interviews, analysis of legal and regulatory proceedings, and extensive, ongoing review and analysis conducted with Indigenous communities featured in the case studies. Our methodological approach to this work is in keeping with the principles of Indigenous and decolonizing research methodologies (e.g. Drawson et al., 2017; Kovach, 2009; Smith, 1999; Wilson, 2008) including the importance of Indigenous people telling their own stories while respecting the many competing demands and pressures on them. For this reason, Indigenous partners engaged with this research and paper in several ways, which they determined: as co-authors; as advisors and reviewers with editorial powers; and as leaders who determined what research and story elements were most important to engage. In addition, the ratio of interviews to secondary information sources was determined by Indigenous partners, to respect community interview fatigue. Finally, we honored the many decades of combined lived and professional experience, knowledge, and expertise of advisors and co-authors as valid forms of applied research and analysis.

The first four authors of this article are part of the Conservation through Reconciliation Partnership, a major collaborative research project funded by the Social Sciences and Humanities Research Council of Canada and matched by in-kind and financial contributions from partners (CRP, n.d.). This partnership brings together Indigenous Elders and knowledge holders, Indigenous youth, Indigenous and Crown governments, researchers, NGOs, conservation agencies, and legal professionals with the aim of transforming the Canadian conservation sector by supporting Indigenous-led conservation and leadership. Youdelis is supporting Grassy Narrows' Land Protection Team in fighting unwanted development and securing funding for their ISPA. Townsend is undertaking community-informed research with the Dasiqox-Nexwagwez?an leadership team on IPCA governance and conducted five semi-structured interviews with leadership and staff currently or formerly involved in the Dasiqox Tribal Park initiative. ${ }^{9}$ Bhattacharyya works with and for Xeni Gwet'in and Yunesit'in, and as part of the Dasiqox-Nexwagwez?an core team, on stewardship, community engagement, and management planning. Moola has worked closely with Grassy Narrows First Nation on plans to remediate the mercury poisoning in their territory and on lobbying the government to fund that remediation. Fobister is a community leader and activist from Grassy Narrows First Nation who helped found Grassy Narrows Environmental Group and was pivotal in their fight to end clearcutting in their territory. He is working closely with Grassy's Chief and Council to support the implementation of their ISPA. He provides an account of Grassy Narrows' use of the ISPA designation in their struggle to protect their lands and waters from extractive industry.

\section{Grassy Narrows ISPA}

The Anishinabe ${ }^{10}$ community of Grassy Narrows is located approximately 80km north of Kenora in northwestern Ontario (Figure 1). The nation's reserve is $22.5 \mathrm{~km}^{2}$, however their Traditional Land Use Area, which follows community trap lines, covers over 7,000 km² (FreeGrassy, 2018). Grassy Narrows First Nation (GNFN) has been ardently resisting —and suffering the consequences of - colonial-capitalist incursion into their traditional territory for over a century.

In the 1950s, the construction of hydroelectric dams flooded portions of GNFN's territory, altered flow patterns and damaged their wild rice harvests. Wild rice harvests today remain contingent upon whether or not dam managers raise waters at sensitive times (Willow, 2012). In the 1960s, the Canadian government moved

\footnotetext{
${ }^{9}$ The small interview program reflects the communities' wishes to avoid further contributing to research fatigue and the preference to conduct interviews with willing members of the initiative's leadership.

10 The term Anishinabe refers to the Indigenous North American people who are also known as Ojibwe and Chippewa. There are several possible spellings, including Anishinaabe, but we adopted the spelling used by Grassy Narrows Chief and Council in the Grassy Narrows Land Declaration.
} 
the community several miles south to a new reserve along a new logging road, which disrupted the nation's systems of social organization, making the nation vulnerable to natural disasters (Vecsey, 1987). This became a social crisis when, in 1970, it was discovered that a chemical pulp and paper mill located upstream in Dryden, Ontario, had been discharging mercury into the Wabigoon river system, which Grassy residents rely upon for their livelihoods. The mill released 10 tonnes of this neurotoxin into the river between 1962 and 1970 , having catastrophic consequences for the health and psycho-social wellbeing of the community, the health and vitality of the river system, and the local economy (Erickson and Vecsey, 1980; Troyer, 1977; Willow, 2012). The provincial and federal governments have been criminally negligent in failing to clean up this spill, which undermines GNFN's constitutionally enshrined rights under Treaty 3 to make their livelihoods through hunting, fishing, and trapping in their territory. More than $90 \%$ of community members tragically continue to suffer from the effects of mercury poisoning 50 years later, including impaired sight, speech, and hearing, loss of muscle coordination, tremors, tunnel vision, and premature death (Bruser, 2020; Harada, 2005; Leslie, 2016; Philibert et al., 2020).

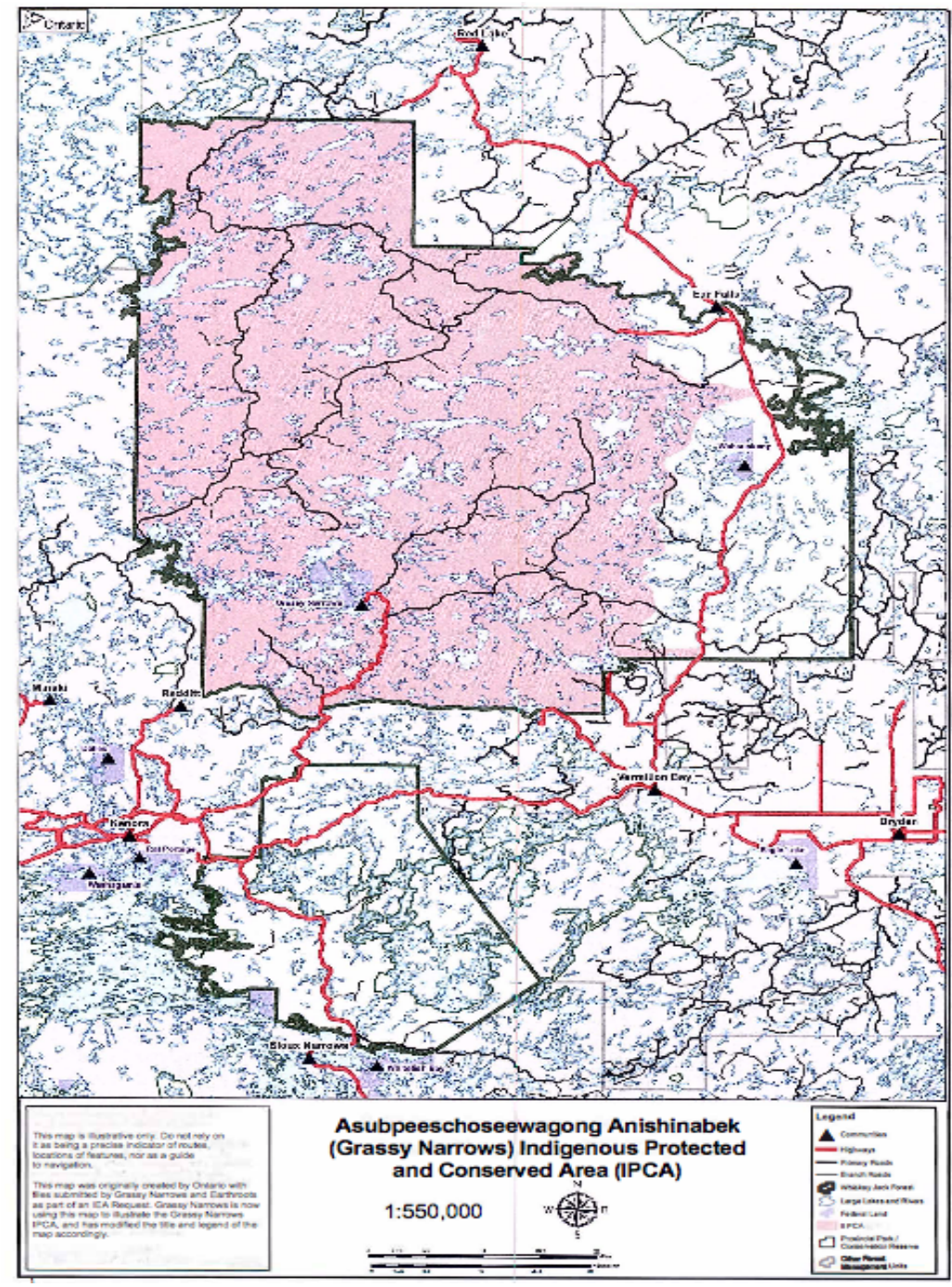

Figure 1: Map of the Grassy Narrows ISPA. 
When forest clearcutting began to accelerate in their territory in the 1990s, degrading hunting and trapping grounds and exacerbating the mercury crisis by releasing mercury settled in the soil (FreeGrassy, 2018; Willow, 2012), the community had had enough. In 1996, a core group of community activists, including J.B. Fobister, formed the Grassy Narrows Environmental Group to protest clearcutting as well as proposals to store nuclear waste near GNFN territory (Figure 2). They successfully eliminated the threat of nuclear waste, but letter-writing campaigns and several demonstrations against clearcutting in Kenora went ignored by the provincial government and the forest industry, and their request to the Ontario Ministry of the Environment to conduct an environmental assessment of proposed logging plans was denied. In April of 2000, Fobister and GNFN trappers, whose yields had declined due to clearcutting, filed an application for judicial review, arguing that the provincial government should have no legal power to grant logging permits in their territory, as their hunting and trapping rights under Treaty 3 are federally protected in the 1982 Constitution Act (Mittelstaedt, 2000; Willow, 2012). This case was intended as a political statement against the unworkable Canadian jurisdictional system where the federal government holds treaty responsibilities and has jurisdiction over "Indians and lands reserved for Indians" (1867 Constitution Act, Section 91(24)), but provincial governments have jurisdiction over natural resources and can thus issue tenures to various resource development companies that directly threaten Indigenous peoples' inherent, treaty and Aboriginal rights and title. Despite directly violating GNFN's rights, in 1999 the Province of Ontario issued a license to develop the Whisky Jack forest (3/4 of which overlaps with GNFN's Traditional Land Use Area) to a multinational paper corporation, Abitibi-Bowater (formerly Abitibi-Consolidated). The judge, citing the complexity of the case, denied GNFN's petition for a judicial review, and required them to bring litigation, a far more complex and lengthy process (Barrera, 2003).

Feeling as though they had exhausted conventional channels of protest, the Grassy Narrows Environmental Group went on to initiate what has become the longest-standing Indigenous-led blockade in Canada on December 3rd, 2002. They set up camp at Slant Lake where community members, youth, and Indigenous and non-Indigenous allies from across Canada joined them in solidarity. When logging trucks found detours around the Slant Lake roadblock and continued to clearcut areas in the northern part of their Traditional Land Use Area, activists initiated roving blockades along with ongoing demonstrations in Kenora and Toronto (Willow, 2012). In 2007, GNFN declared a moratorium on clearcutting within their territory, and together with one of their partner organizations, the Rainforest Action Network, successfully campaigned to pressure corporations to boycott wood from the area (RAN, 2008). These combined efforts led Abitibi-Bowater to relinquish their license to log the Whisky Jack Forest in 2008 (Gorrie, 2008), and no commercial logging has happened since. The blockade has not ceased, however, as the long-term threat of logging is not resolved.

In 2011, GNFN brought their case to the Ontario Superior Court, arguing that the Province had no legal right to take up lands in Treaty 3 territory to issue logging permits, as these infringe on their Treaty rights held with the federal government. Justice Sanderson ruled in favor of GNFN, upholding the Anishinabe understanding of Treaty 3 as being signed with Canada in 1873, not Ontario, and thus only Canada can issue forestry permits that may affect treaty rights (McIvor, 2014). This ruling was overturned by the Ontario Court of Appeal, which held that Ontario owns the Crown lands in Treaty 3 territory and, as Ontario has jurisdiction over natural resources, the Province is able to issue tenures without federal supervision (FreeGrassy, 2015; Keewatin v. Ontario (Natural Resources), 2013). GNFN appealed this decision to the Supreme Court of Canada, which ruled against GNFN, confirming that Ontario did under Crown law have authority to take up lands in Treaty 3 territory without involving Canada (Grassy Narrows v. Ontario, 2014). However, the court held that "Ontario has all the constitutional obligations of the Crown, is bound by and must respect the treaty, must fulfil treaty promises and must administer 'Crown' lands subject to the terms of the treaty and First Nations' interest in the land" (McIvor, 2014). As the threat of logging remains, GNFN then mobilized the IPCA designation for their territory in an effort to ensure that the Province upholds their treaty rights.

Three years after a community referendum in 2015, where 75\% supported banning industrial logging entirely, GNFN's Chief and Council declared their Traditional Land Use Area an Indigenous Sovereignty and 
Protected Area (ISPA) through the 2018 Asubpeeschoseewagong Anishinabek Aaki Declaration ${ }^{11}$ (GNFN Land Declaration) (FreeGrassy, 2018). The GNFN Land Declaration is a Grassy Narrows law established pursuant to their inherent right to self-determination. The GNFN government declared the ISPA following conservative Premier Doug Ford's promise to open up the North to industrial logging (Welsh and Bruser, 2020). The ICE report had been released seven months prior to the Land Declaration, and with the growing recognition of IPCAs federally, GNFN intended to use the designation to send a message to the Conservative Ford government that they would not stand to have their territory re-opened for clearcut logging.

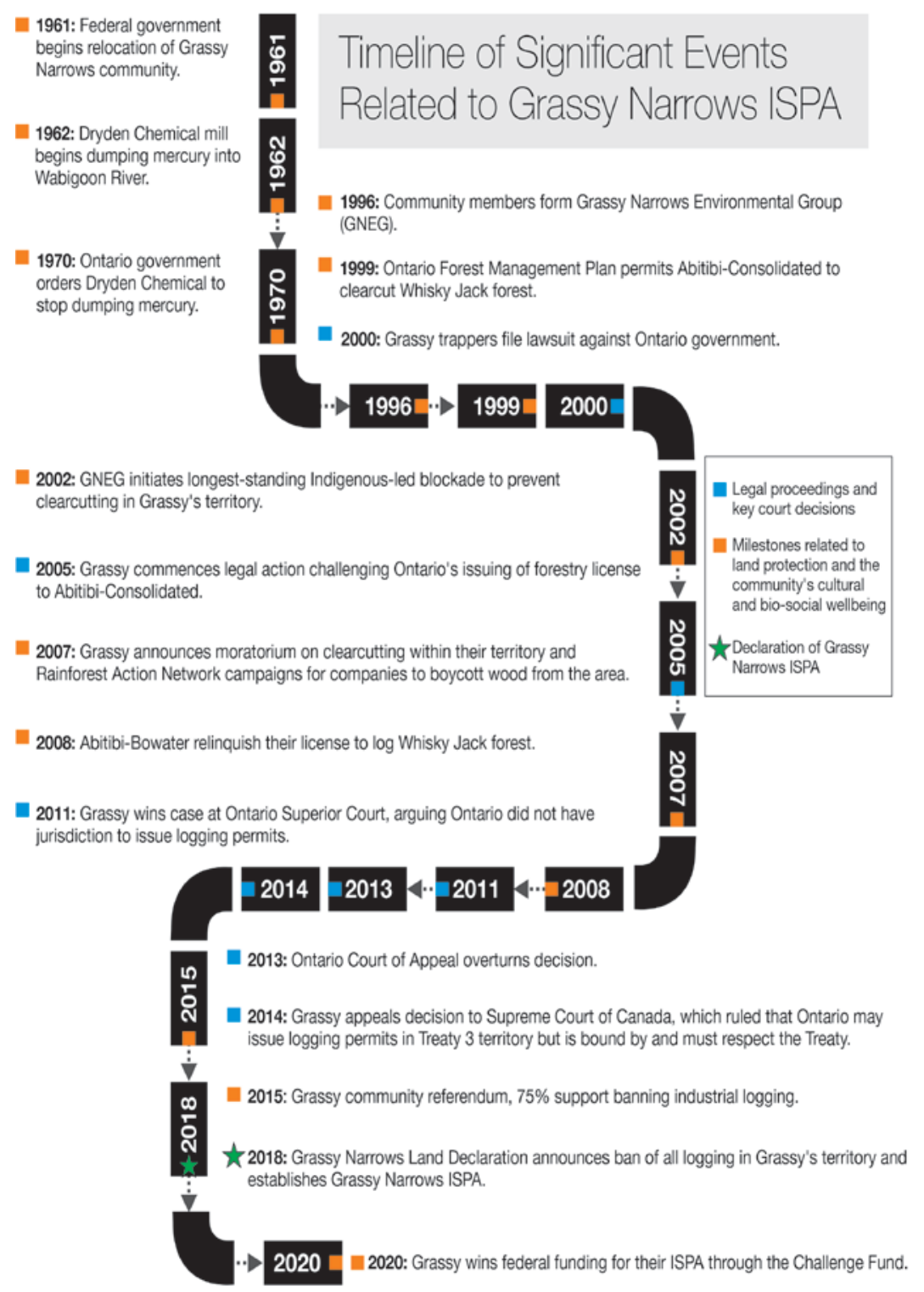

Figure 2: Timeline of significant events related to Grassy Narrows ISPA.

\footnotetext{
${ }^{11}$ The ICE report was released in March, 2018, and GNFN's Land Declaration was issued in October, 2018.
} 
Within the context of their century-long fight for environmental justice, declaring the ISPA was in part a strategic move to assert Grassy Narrows' own Indigenous laws, and bring the Ontario Ministry of Natural Resources (OMNR) to the negotiating table to discuss removing GNFN's Traditional Land Use Area from forest management planning, to ensure that no other company picks up a license to clearcut the Whisky Jack forest. The declaration was successful in that aim, as talks are now ongoing between Grassy Narrows and the OMNR about maintaining a "no harvest area" in the next Whiskey Jack Forest Management plan. Combined with the ongoing blockade and campaign to ensure companies boycott wood from GNFN territory, the nation is hopeful that OMNR will be moved to action and remove their territory from forest planning in the long term. Declaring their territory an ISPA was therefore the culmination of a complex, long-term strategy to protect their land, culture, and livelihoods from colonial-capitalist annihilation. Although the long-term political vision for the ISPA is to secure territorial sovereignty and self-determination, and rejuvenate and restore the land, and with it Anishinabe cultural life, language, and intergenerational knowledge transfer, the Land Declaration was also a tool to address the immediate threat of further extraction, which is a precondition for socioecological renewal.

They chose to call the area an ISPA rather than an IPCA to call attention to the fact that stewarding their traditional territory is their sovereign right. The Declaration states:

We assert our inherent sovereignty and our inalienable right to self-determination on our Indigenous homeland. Our land and our rights are given by the Creator and only the Creator can take them away. Some of these rights are recognized under Treaty 3, the Constitution Act of 1982, the Canadian Charter of Rights and Freedoms, Canadian statutory and common law, and under international human rights instruments that are binding on Canada.

The Declaration highlights the importance of the land as the foundation of the Anishinabe way of life, underscoring that the devastation of the land "threatens to annihilate our very existence as a people" (FreeGrassy, 2018). The document lists prohibited activities as well as land uses that will be allowed for GNFN community members and for non-GNFN residents with a permit from GNFN's government, sketching out the foundations of a new Indigenous-led conservation economy centered around remediation, restoration, deeply sustainable harvesting ${ }^{12}$ of plants and animals, and eco-tourism.

GNFN has received federal support for their ISPA, winning funding from the Target 1 Challenge Fund program (Government of Canada, 2018) as well as federal funding for the Indigenous Guardian program, providing two years of funding and greater government recognition for their budding ISPA as well as capacity building for local Indigenous Guardians to formally monitor flora and fauna in their territory. Chief and Council are working with a community Land Protection Team, with Fobister serving as Lead Lands Negotiator for the nation.

Despite the federal support, the fight continues for the government of Ontario to fully respect the Land Declaration along with GNFN's legal authority, sovereignty, and rights. While the community moratorium, referendum and Land Declaration are binding under GNFN law, and the Supreme Court has affirmed that the Province must respect GNFN's Aboriginal and Treaty rights, Ontario does not formally recognize the Land Declaration. The presumption that the Crown can act unilaterally in Treaty 3 territory -and that the Crown legal system is itself legitimate, just, and should trump Indigenous legal systems - is based on the racist assumption that Indigenous peoples were too primitive to have legitimate legal systems or sovereign rights over their territories upon contact (Coulthard, 2014). It remains difficult to discuss issues around jurisdiction with provincial authorities, and although stewarding their territory is their sovereign right, at times GNFN chooses strategically to speak of their ISPA as merely an Indigenous Protected Area in talks with the OMNR, dropping the word "sovereignty" from its title. While GNFN's Land Declaration was successful in bringing OMNR to the negotiating table regarding commercial logging, the ongoing threats posed by other extractive

12 The OMNR claims that clearcutting is sustainable harvesting, which GNFN ardently disputes. 
industries must be neutralized if GNFN's ISPA is to reach its full potential and contribute to reconciliation through conservation.

In an investigative article in the Toronto Star, Sheila Wang reported that as of April 2021, the Ontario government has allowed prospectors to stake nearly 4,000 gold mining claims within GNFN's ISPA (Wang, 2021). If developed, these claims would threaten GNFN's constitutionally enshrined rights and community members' way of life and would undermine the potential of their federally supported ISPA. That GNFN is facing the prospect of unwanted mining in their territory — which remains poisoned by mercury and extensively logged - makes a mockery of reconciliation. The provincial Conservatives have come under fire from the opposition party, activists, and academics for the move (Benzie, 2021; Youdelis et al., 2021), and activists and NGO partners have organized letter writing campaigns and virtual solidarity rallies (DSF, 2021; FreeGrassy, 2021). Given the public support for GNFN's Land Declaration, the government has not moved forward with any of these claims, but the threat of extraction looms large until the Ontario government respects GNFN's Land Declaration and withdraws the ISPA from all future mining, logging, and other extractive activity.

A further challenge is the issue of funding. Although GNFN received funding through the Challenge Fund for two years, securing ongoing sources of funding to support ISPA management is onerous and time consuming. As GNFN's territory has been impacted by industrial development and mercury poisoning, they do not meet the ecological criteria that motivate many of the big conservation donors, who are focused mainly on intact ecosystems. If IPCAs are to be effective in biocultural conservation, they must be understood not only as mechanisms to meet Canada's area-based conservation goals, but as integral to Indigenous peoples' Aboriginal and treaty rights (see Zurba et al., 2019). The fate of the land and of Indigenous peoples are often intimately linked, and supporting Indigenous resurgence through ecosystem protection and restoration supports area-based conservation goals while respecting Indigenous peoples' inherent and constitutionallyenshrined rights and responsibilities to their lands and waters.

\section{Dasiqox-Nexwagwez?an, Tsilhqot'in Territory (British Columbia)}

As part of one and a half centuries of resistance to colonial and capitalist intrusions, in October of 2014 the Tsilhqot'in communities of Xeni Gwet'in and Yunesit'in announced Dasiqox-Nexwagwez?an (also known as Dasiqox Tribal Park). Tsilhqot'in communities include approximately 3,000 citizens from six First Nations that each have their own elected Chiefs and Governing Councils, and are collectively represented by the Tsilhqot'in National Government (Borrows, 2015; Tŝilhqot'in National Government, 2020). ${ }^{13}$ None of the Tsilhqot'in communities have signed treaties although in 2019 the communities signed a tripartite reconciliation agreement with the Province of B.C. and Canada ${ }^{14}$ (Tsilhqot'in Nation et al., 2019). DasiqoxNexwagwez?an is about $3,550 \mathrm{~km}^{2}$ and located in the southern interior of B.C. in the shared Caretaker Areas of the Yunesit'in and Xeni Gwet'in First Nation Governments ${ }^{15}$ (Dasiqox Tribal Park Initiative, 2020; Figure 3). Xeni Gwet'in and Yunesit'in established Dasiqox-Nexwagwez?an in large part to make clear their assertion of jurisdiction, rights, and title, in the context of decades of sustained opposition to pressures from extractive resource industries (e.g. mining and logging) throughout their territory.

\footnotetext{
13 The Xeni Gwet'in First Nation has 455 registered members and Yunesit'in Government has 493 registered membersboth with just under half of their members living on reserve (Indigenous and Northern Affairs Canada, 2020a, 2020b).

14 The Gwets'en Nilt'I Pathway Agreement is a "historic reconciliation agreement to support Tŝilhqot'in selfdetermination, five years after the landmark judgement of the Supreme Court of Canada in the Tsilhqot'in Nation Decision" (Government of Canada, 2019). This tripartite agreement is intended to facilitate transformative change for Tsilhqot'in peoples and Tsilhqot'in-Crown relationships (Tsilhqot'in Nation, Canada, \& British Columbia, 2019).

${ }^{15}$ Dasiqox-Nexwagwez?an is remote, accessible by highway and then unpaved roads about $125 \mathrm{~km}$ southwest of the town of Williams Lake, which is located about $550 \mathrm{~km}$ north of Vancouver.
} 
A major impetus for declaring the Tribal Park ${ }^{16}$ was the Supreme Court of Canada's landmark ruling in June 2014 that accorded title to the Tsilhqot'in in a portion of the Xeni Gwet'in Caretaker Area, and affirmed specific Tsilhqot'in rights in some areas around the title lands. This case, of "ground-shifting implications", was the first in Canada to affirm Aboriginal title, with the court acknowledging that Tsilhqot'in selfgovernment and legal orders pre-existed the Crown's assertion of sovereignty (Borrows, 2015: 704). ${ }^{17}$ Dasiqox-Nexwagwez?an is adjacent to approximately $1,800 \mathrm{~km}^{2}$ of territory where the Supreme Court of Canada affirmed that Tsilhqot'in have pre-existing and unalienated title; a portion of Dasiqox-Nexwagwez?an includes areas where the courts affirmed Tsilhqot'in rights. The Court also ruled that the province failed to uphold its duty to consult with the Tsilhqot'in Nation by issuing forestry permits and removing timber from large portions of Tsilhqot'in territory (Woodward \& Company, n.d.). While the court recognized Tsilhqot'in title and rights in a portion of their territory and claim area, the Tsilhqot'in maintain they never relinquished any of their territory to the Crown. Thus the establishment of Dasiqox-Nexwagwez?an is one means of reminding the Crown that the Tsilhqot'in continue to protect, and exercise their responsibility to care for, their whole territory.

Rather than continually reacting to the agendas imposed by external actors and forces-particularly mineral and forestry pressures and Crown government agendas-Dasiqox-Nexwagwez?an is a declaration of how Tsilhqot'in people will live in their territory now, with past and future generations in mind. Dasiqox names the headwaters, river, and watershed that are the heart of the area, and Nexwagwez?an translates to [it is] "there for us." Dasiqox-Nexwagwez?an has cultural revival and a conservation economy-as well as ecological regeneration and protection — at the core of the initiative. As one former Chief of Xeni Gwet'in First Nation stated, Dasiqox-Nexwagwez?an is "part of our Indigenous rights and assertion as Indigenous peoples in our lands and water" (M. Baptiste, pers. comm., 2020). Dasiqox-Nexwagwez?an is therefore, "a new name for a very old relationship" (Bhattacharyya et al., 2018: 3).

Dasiqox-Nexwagwez?an protects ecological, cultural, and livelihoods values, including: rivers, lakes, mountains, forests, areas impacted by decades of logging, and culturally and ecologically important plants and wildlife. ${ }^{18}$ At a governance level, establishing Dasiqox-Nexwagwez?an involves: articulating traditional law and governance principles; ecosystem planning, monitoring, and stewardship; and engaging in the government-to-government negotiations necessary for other agencies to respect Tsilhqot'in jurisdiction in the area. ${ }^{19}$ On the ground, the initiative supports cultural events, conducts applied research, stewards and restores important areas, and engages Tsilhqot'in elders and community members in its efforts. The Tsilhqot'in's long term governance goal in establishing Dasiqox-Nexwagwez?an is to re-establish Tsilhqot'in governance over the lands and waters therein, though the types of negotiations with the Province that would enable this have not materialized (Chief Myers Ross, pers. comm., 2020). As described in the Nexwagwez?an Community Vision and Management Goals for Dasiqox Tribal Park; Summary (2018),

\footnotetext{
${ }^{16}$ Initially called Nexwagwez?an - Dasiqox Tribal Park with guidance from the elders, the leadership team has recently renamed it Dasiqox-Newagwez?an, dropping the term "tribal park" because the term "park" has negative connotations for some community members and neighbours (i.e. evoking concerns that if it is a park community access and use could be curtailed).

17 The case reaffirmed earlier decisions that held that government infringement on Aboriginal title is only justifiable in the case of sufficient and extenuating public interest while still upholding their fiduciary responsibility, and that where proposed resource development exists governments must consult with Aboriginal peoples (Borrows, 2015).

${ }^{18}$ Dasiqox includes the protection of the headwaters of the Dasiqox lakes and river watershed. The lakes and watershed not only provide essential drinking water to Tsilhqot'in communities and their food sources, including several endangered salmon populations, but also flow as headwaters into the ecologically and culturally significant Fraser River watershed, which is home to over $60 \%$ of BC's population.

${ }^{19}$ Dasiqox-Nexwagwez?an is jointly governed by Yunesit'in Government and Xeni Gwet'in First Nations Government and currently relies on grant-based funding. Its supporters include environmental, philanthropic, and conservation organizations, local naturalist associations, as well as members of the public from near and far. It has also been subject to some local opposition, particularly from the municipality of Williams Lake.
} 
Asserting our rights, title, and caretaker role is one way that we are healing and repairing the damage that was done to us as people, and our lands, over a century of mismanagement by other governments (p. 3).

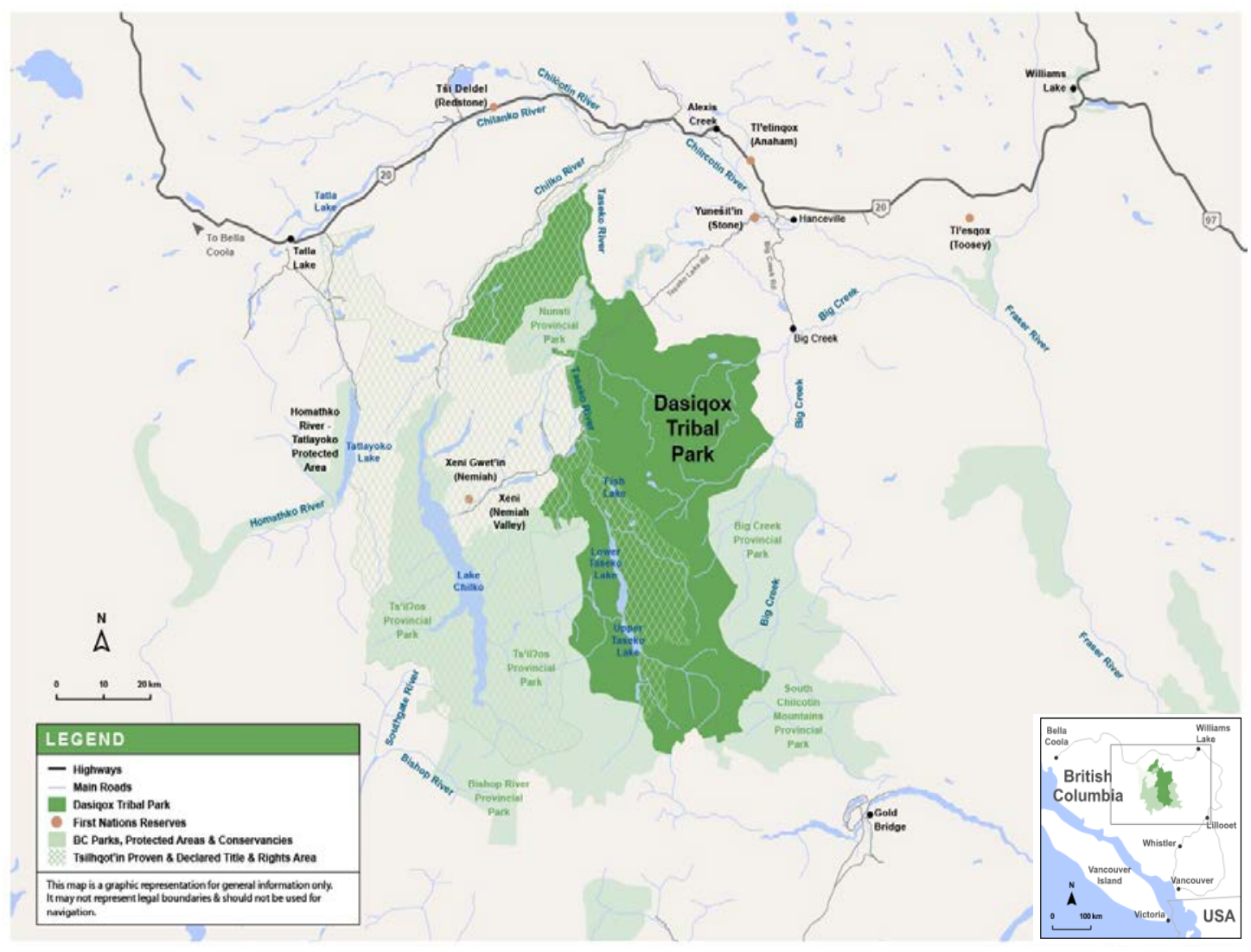

Figure 3: Map of Dasiqox-NexwagwezPan and Tsilhqot'in Proven Title and Rights Area. Source: Dasiqox Tribal Park Initiative, 2021

Tsilhqot'in communities continue to resist industrial incursion in their territories, mobilizing various strategies, of which Dasiqox-Nexwagwez?an is one of the latest. Following numerous historical traumas and intensified ranching, logging, mining, and road building throughout the $20^{\text {th }}$ century, in 1989 Xeni Gwet'in First Nation (formerly the Nemiah Valley Indian Band) issued the Nemiah Declaration. The declaration stated that there can be no commercial road building, commercial or clear-cut logging, commercial mining or mining exploration, or flooding or dam construction in their territory (Nemiah Valley Indian Band, 1989). Efforts to uphold the declaration have included roadblocks to protect the remaining unlogged portion of Xeni Gwet'in territory, and a series of court battles that set important legal precedents (Woodward \& Company, n.d.). In 2007 a judge found that Xeni Gwet'in have commercial rights to hunt and trap throughout the entirety of their claim area of about 4,380 km² (Figure 3; Townsend et al., 2019; Woodward \& Company, n.d.). Subsequent legal proceedings continued in other forms, leading to the 2014 Tsilhqot'in title recognition by the Supreme Court of Canada (Tsilhqot'in Nation v. British Columbia, 2014), as well as the Tsilhqot'in's 30-year fight against a proposed open pit copper-gold mine in their territory (Impact Assessment Agency of Canada, 2020). 
If initiated, the mine would have devastating impacts on Tsilhqot'in communities; it is an acute example of the relentless pressures facing Tsilhqot'in territory that continue to undermine their IPCA efforts.

The story of how Tsilhqot'in have actively resisted the construction and operation of the open pit gold and copper mine - known as the proposed Prosperity or New Prosperity mine - exemplifies how Dasiqox Nexwagwez?an is an assertion of Indigenous rights and responsibilities, and a stand against extractive capitalism (see Figure 4 for a timeline). It also exemplifies the type of ongoing and costly threats that many First Nations face before, during and after IPCAs are declared. The original and revised mining proposals were within the Tsilhqot'in declared rights area. If constructed, the projects would have devastated a particularly sensitive, ecologically and culturally significant part of Tsilhqot'in territory, an area Chief Joe Alphonse describes as "sacred to us a church" (Townsend et al., 2019). The proposed mining activities ${ }^{20}$ included draining Teztan Biny (Fish Lake, a cultural keystone place) and the downstream wetlands and filling the pits with mine tailings; processing 70,000 tonnes of ore per day for 20 years; and developing extensive infrastructure such as tailings and waste rock areas, a concentrator facility, and $125 \mathrm{~km}$ of transmission line corridors (Impact Assessment Agency of Canada, 2020).

Xeni Gwet'in, Yunesit'in, Tsilhqot'in National Government, and allies Friends of Nemaiah Valley joined together in an exhaustive effort to fight the mine through a full review process by the Canadian Environmental Assessment Agency (CEAA). In 2010, on the recommendation of the CEAA review panel, the federal government completely rejected the proposed Prosperity Gold-Copper Mine (a highly unusual outcome). Shortly after, the provincial B.C. Environmental Assessment Office approved a revised version of the same project (called the New Prosperity Gold-Copper Mine) by the same company. A second full federal review by CEAA ensued, with the Tsilhqot'in and allies raising funds and organizing efforts to fight the project yet again. In their scathing report, CEAA noted that the proposed New Prosperity Gold-Copper Mine would have adverse impacts on fish and fish habitat, water quality, and wetland ecosystems, and would adversely impact Indigenous peoples' culture, including traditional use of their lands (Impact Assessment Agency of Canada, 2017b). In 2014, the federal government issued its final decision, rejecting the proposed project for the second time.

Within months of the federal government's second rejection of New Prosperity and the Supreme Court's Tsilhqot'in decision, the Tsilhqot'in announced the creation of Dasiqox Nexwagwez?an in October 2014. The announcement was an assertion of Tsilhqot'in jurisdiction and an alternative vision for their territory. Still, the mining proponent continued to mount legal challenges to the Tsilhqot'in and federal government decisions and to propose industrial activities in the region, which now comprised part of the Tsilhqot'in's IPCA. In their final days of office in 2017—while Tsilhqot'in communities and the Tsilhqot'in National Government were in a declared state of emergency due to catastrophic wildfires-the provincial government issued a permit for the mining proponent, to conduct "exploration" in the same location ${ }^{21}$ (Carol, 2017; Lavoie, 2019a). Notwithstanding the timing of the decision, which was very upsetting to the communities, the mine could not be built and operated without the federal approval that had already been twice denied, calling into question the purpose of further exploration activities. The exploration permit allowed for extensive road building and expansion, drilling and excavation in Dasiqox-Nexwagwez?an. The Canadian Impact Assessment Agency (formerly CEAA) issued a statement to Taseko Mines Ltd. stating that the proposed activities went beyond exploration, and were more accurately mining, which was not permitted, and threatened legal enforcement, fines, and court action against the proponent (Impact Assessment Agency of Canada, 2017a). Following a prolonged series of legal actions by the Tsilhqot'in National Government and Taseko Mines Ltd., this permit catalyzed the Tsilhqot'in to mount a blockade in 2019 (the latest of several in 30 years of re-

\footnotetext{
20 The proposal to drain Teztan Biny was part of the first mine proposal, later revised on account of strong Tsilhqot'in opposition and the high degree of impacts this activity would have caused. Teztan Biny and Nabas, the surrounding area, hold immense ecological and cultural significance to the Tsilhqot"in.

${ }^{21}$ The wildfires were extensive, ripping through 761,000 hectares in the B.C.'s interior and Tsilhqot'in territory (Stacey et al., 2019). Tsilhqot'in were in the process of evacuating from their communities and government offices when the provincial government granted the permit to Taseko Mines Ltd.
} 
sistance), as a last resort to prevent Taseko Mines from entering the territory and Dasiqox Nexwagwez?an. The Tsilhqot'in also submitted an appeal to the United Nations Special Rapporteur on the Rights of Indigenous peoples (Townsend et al., 2019).

The Province's granting of the exploration permit exacerbated crisis conditions for the Tsilhqot'in communities already strained for capacity, exhausted from two full federal review processes, traumatized by the long-term effects of massive wildfires, and dealing with extensive post-wildfire flooding and food shortages. Meanwhile, Dasiqox-Nexwagwez?an governance and planning activities were continually diverted to defend against mining and other extractive resource pressures. This series of permits, regulatory loopholes, and pressures raise questions about the integrity of the Provincial reconciliation framework agreement (the 2016 Nenqay Deni Accord), which predated the tripartite reconciliation agreement in 2019. In 2020, the Supreme Court of Canada ruled that Taseko Mines Ltd. could not appeal the federal government's double rejection of their proposed project. While effectively this means the project is dead-after three decades of Tsilhqot'in resistance - the communities are only cautiously optimistic. The specter of a mining project looms in the background for as long as the mineral tenures are held. Taseko Mines Ltd.'s mineral tenures do not expire until 2035, and any company could submit a new mining proposal and trigger a new environmental assessment process (Hoogeveen, 2015; Lavoie, 2020). Thus despite all legal and regulatory actions affirming Tsilhqot'in title and rejecting the proposed mine, Dasiqox-Nexwagwez?an remains in a precarious position in practice, so long as it is not formally protected by some form of Crown legislation, agreement, or until mineral tenures are retired or bought out.

Dasiqox-Nexwagwez?an's ongoing story of resistance reveals one of the central paradoxes of IPCAs: because they are Indigenous-led and generally not co-designated under Crown legislation, Indigenous jurisdiction is undermined at the same time as it is asserted. This paradox challenges progress on reconciliation and the full recognition of Section 35 Indigenous rights, including the right to self-governance. The 2019 reconciliation agreement between B.C., Canada, and the Tsilhqot'in National Government and six Tsilhqot'in communities is intended to facilitate transformative change for Tsilhqot'in peoples and Tsilhqot'in-Crown relationships. The agreement explicitly supports Tsilhqot'in self-determination and self-governance (including Tsilhqot'in jurisdiction, responsibilities, and law) in alignment with UNDRIP and the Constitution Act, 1982, and commits to making progress on Tsilhqot'in priorities which include nen (lands, water, and resources), and sustainable economic development (Tsilhqot'in Nation, Canada, \& British Columbia. 2019). The Gwets'en Nilt'l Pathway Agreement is an important framework for transformation. Yet without also transforming conventional resource-based economies and associated decision-making processes, it is unclear how these priorities are achievable. Dasiqox-Nexwagwez?an presents opportunities to actualize reconciliation goals on the ground, yet to date issues persist that hinder progress. Xeni Gwet'in, Yunesit'in, and Tsilhqot'in National Governments must continually defend their territories from ongoing resource development pressures permitted by Crown governments even as they attempt to develop a management plan and stewardship framework for their territory and Dasiqox-Nexwagwez?an.

Another aspect of this paradox is illuminated by the Crown's fragmented affirmation of Indigenous title. Since the Supreme Court of Canada only affirmed Tsilhqot'in title to a portion of their territory (itself a huge victory) it simultaneously reinforced challenges to the Tsilhqot'in abilities to exert greater influence over the non-titled claim area. For the Tsilhqot'in, the boundaries of title and non-title land are an externally imposed distinction. As discussed, Tsilhqot'in's enduring responsibilities to care for their lands and waters extend across their entire territory, with Dasiqox-Nexwagwez?an clearly articulating this worldview (irrespective of Crown or industry's agreement). As former Chief of Yunesit'in Government stated,

We couldn't be fazed by the fact that there is a declaration and it didn't include certain parts [of our territory]. We said this whole area is significant to us. It's still sacred to us...We still think this whole area is significant to our survival and to our culture we're not going to abandon this area. We still have to honor our responsibilities, we still have to honor our stories that reside there and the animals that live there. (Chief Myers Ross, pers. comm., 2020) 
However, the Tsilhqot'in's vision for their territories and IPCA remains subject to Crown priorities around resource extraction. This tension points to the political nature of Crown support for IPCAs, which in practice occurs on a case-by-case basis.

Dasiqox Nexwagwez?an demonstrates how the process of establishing an IPCA can be actively undermined, disrupted and challenged, even as Crown governments voice support for them in principle. Given the small size and limited resources available to the Tsilhqot'in governments, the same few elected leaders and staff members who would be engaging in proactive community planning through DasiqoxNexwagwez?an, are repeatedly forced into emergency defensive actions (legal action, negotiations, media campaigns, and road blockades). This prevents them from devoting time as preferred: realizing their own local conservation, cultural, and economic visions for their territory. For Crown governments, industrial development and resource management processes are overseen by different staff and elected officials than those who are focused on Indigenous reconciliation and protected areas. There may be one ministry supporting IPCAs (e.g. B.C. Ministry of Indigneous Relations and Reconciliation) while other ministries actively undermine and disregard them through "business as usual" permitting and resource extraction (e.g. B.C. Ministry of Energy, Mines and Low Carbon Innovation and the B.C. Ministry of Forests, Lands, Natural Resource Operations and Rural Planning). In Indigenous governments, such as those governing Dasiqox Nexwagez?an, the same few people (staff and elected officials) must deal with all portfolios. Therefore, IPCAs are not only compromised by the environmental impacts and threats of extractive capitalism, but by the ongoing procedural and bureaucratic demands of resisting or engaging with externally driven consultation, permitting, and review processes.

Finally, existing government permitting systems and legislation favor Crown and industrial interests, further contributing to the paradox of IPCAs. Although some forestry companies have accommodated Tsilhqot'in requests to defer their tenures and leave certain areas alone while community-led land use planning processes are ongoing, the Tsilhqot'in continue to be "stonewalled" by the mining sector (Chief Myers Ross, pers. comm., 2020). Liberal ideologies of private property regimes underpin free-entry mineral staking regimes in B.C. and legally undermine Indigenous governance (Hoogeveen, 2015). As the Tsilhqot'in reject colonial models of conservation, Dasiqox-Nexwagwez?an is not protected under Crown legislation, and it thus remains vulnerable to mining interests and the forestry sector, even though it is recognized in the national ICE report (2018).

In 2019, the Province of B.C. moved to ensure provincial laws are aligned with global standards through the United Nations Declaration on the Rights of Indigenous Peoples Implementation Act, which enshrines the principles of free, prior and informed consent (Bill 41 - 2019, 2019; Singh et al., 2019). Yet to date, B.C.'s mining laws continue to disenfranchise Indigenous peoples while privileging corporate interests. Legislative reform may be one avenue that could help eliminate intractable conflicts such as the struggle over Tsilhqot'in territory in the future, but to date little progress has been made and change is likely to be slow. Irrespective of new legislative tools, we expect the number of IPCAs being established across B.C. and Canada to increase. These paradoxes will continue to surface until we bring about deeper changes to our environmental governance processes that respect Indigenous governance, authority, and jurisdiction. 


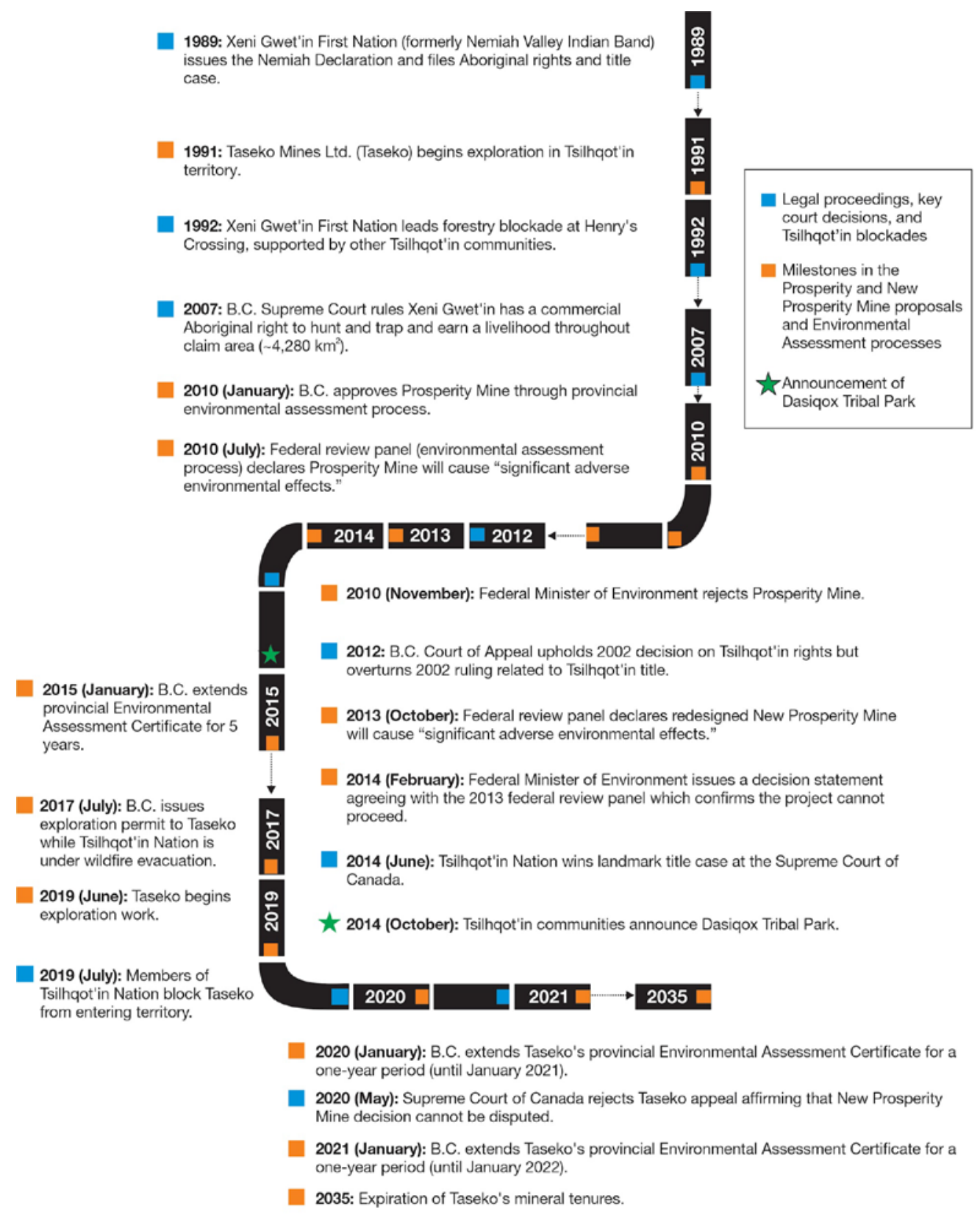

Figure 4. Timeline of milestones related to Dasiqox-Nexwagwez?an

\section{IPCAs and alternative sustainabilities}

Driven by climate change, habitat loss and fragmentation fueled by unsustainable resource use, the global biodiversity crisis has prompted 196 countries, including Canada in 1992, to sign onto the UN's Convention on Biological Diversity and commit to steadily increase protected area coverage, which can simulta- 
neously help to mitigate anthropocentric climate change (IPCC, 2019; Smith et al. 2020). This included Canada's commitment to protect $17 \%$ of the land base and inland waters and $10 \%$ of marine areas by the end of $2020^{22}$ (Aichi Target 11, or Canada Target 1), and the ambitious new target of protecting $30 \%$ of domestic lands and waters by 2030. Given the strained relationship between state-led conservation and Indigenous peoples, and the failure of market-based conservation to stave off further biodiversity decline, the ways in which states meet area-based targets are of utmost concern. Recognizing that the colonial-capitalist paradigm of conservation and development has been devastating for many Indigenous peoples and environments globally, scholars in political ecology increasingly call for decolonial models of conservation and for alternative sustainabilities both within and outside of protected areas (Büscher and Fletcher, 2020; Cavanagh, 2017; Moola and Roth, 2018; Sullivan, 2017; West and Aini, 2018).

As Büscher and Fletcher (2020) note, many Indigenous-led conservation initiatives have long embodied convivial conservation's vision, and Bernauer and Roth argue that IPCAs

...and other forms of Indigenous-led conservation [are] places [where we can] reclaim our collective responsibilities towards the land, pilot economies rooted in Indigenous values, and model appropriate collaborative relationships that can provide for a post-capitalist future. (2021: 216)

In the report We Rise Together (Indigenous Circle of Experts 2018), ICE discusses the productive potential of Indigenous economies and legal traditions to inform alternative development models within and outside of IPCAs, particularly conservation economies. ${ }^{23}$ They write:

Since time immemorial, Indigenous Peoples in Canada have been diligent and ingenious cultivators of biological diversity through advanced economic practices that were founded on natural law. Indigenous economies followed Indigenous worldviews, which understand that human systems are part of, and must remain in balance with, ecosystems. The outcome and effect of these worldviews and economic practices was abundant, thriving biological diversity (ICE, 2018: III).

The visions for both Dasiqox-Nexwagwez?an and Grassy Narrows ISPA include the creation of Indigenous conservation economies which combine cultural and subsistence economies with initiatives such as ecological restoration projects, sustainable harvesting of plants and animals, Indigenous Guardians programs, and ecotourism ${ }^{24}$, with the goal of enhancing community self-sufficiency and self-determination. When realized, these projects have the potential to model alternative sustainabilities that (re)imagine a positive role for humans within our ecosystems: for example, an economy that prioritizes ecological and community health, or what Tla-o-qui-aht Elder Joe Martin calls "abundability" (as opposed to "sustainability"), a cultural teaching that ensures the thriving of ecosystems for many generations to come (Gilpin, 2020). The reciprocal integration of human and non-human societies in IPCAs thus offers a powerful vision for the future of conservation

\footnotetext{
${ }^{22}$ Canada did not meet its 2020 targets.

${ }^{23}$ ICE $(2018,39)$ describe conservation economies as "the pursuit of social and economic benefits through the conservation of ecosystems within an area, or a variety of economic arrangements that have been redesigned to restore, rather than deplete, natural and social capital, based on the premise that life comes from nature and depends on its capacity to maintain healthy ecosystems."

${ }^{24}$ While Büscher and Fletcher (2020) are highly critical of the commodification of in situ natural resources through tourism, ecotourism is one strategy among many that Indigenous nations are employing to enhance community selfsufficiency within the broader colonial-capitalist economy.
} 
practice as well as for the development of alternative economies that address the root causes of climate change and biodiversity loss: colonial-capitalist dispossession and growth (Davis and Todd, 2017; Peet et al. 2011). As conventional fortress-style protected areas are increasingly threatened by the environmental externalities of colonial capitalism, including but not limited to climate change and resource development pressures (CPAWS, 2012; Lemieux et al, 2011), the alternative visions for conservation and development that IPCAs espouse may offer the strongest protection for biodiversity moving forward (Persaud 2021; Schuster et al., 2019).

The viability of Grassy Narrows ISPA and Dasiqox-Nexwagwez?an —like many established and emerging IPCAs - however, are threatened by the unsustainable colonial-capitalist paradigm that continually attempts to dispossess Indigenous peoples from their territories for capitalist gain. As the Yellowhead Institute's Land Back (2019) report states, extractive industry represents one of the primary drivers of Indigenous land alienation in Canada. Canada leads the world in mining extraction globally, with domestic exports making up 19\% of total national exports (Mining Association of Canada, 2020). The forestry sector contributed CAN\$25.8 billion (US\$20.4b) to Canada's GDP in 2018, accounting for about 7\% of total exports, and contributes to a host of secondary industries (Government of Canada, 2020b, 2020c). As stated in the Land Back report (2019: 25):

[The] state-industry complex that motivates land alienation is a major economic driver of the Canadian economy. It is the basis of settlement in the country and a central organizing force of capitalism. It is also in many cases the major destructive force of Indigenous economies.

Further, the colonial legal system provides loopholes and barriers to upholding Indigenous jurisdiction and Aboriginal and treaty rights. Yellowknives Dene scholar Glen Coulthard (2014) demonstrates that Indigenous rights are often surreptitiously undermined by the very mechanisms meant to uphold them, as state agencies can justifiably infringe on these rights for a host of reasons, "ranging from conservation to settlement, to capitalist nonrenewable resource development, and even to protect white interests from the potential economic fallout of recognizing Aboriginal rights to land and water-based economic pursuits" (loc 2677, ebook). Colonial power relations permeate the legal system, exemplified by the disproportionate number of court cases won by government and industry in land disputes compared to those won by Indigenous governments and nations. The Yellowhead Institute reports that $90 \%$ of injunctions filed against First Nations by government were granted and $81 \%$ of injunctions filed against First Nations by corporations were granted. Meanwhile, $81 \%$ of injunctions filed against corporations by First Nations were denied, as were $82 \%$ of injunctions filed against the government by First Nations (Yellowhead Institute, 2019). Crown agencies are also slow to actually implement changes when First Nations do win significant court cases, such as Tsilhqot'in's landmark title win.

Siloing Indigenous issues into specific departments or ministries within Crown governments similarly furthers colonial-capitalist agendas. As previously noted with respect to Dasiqox-Nexwagwez?an, sympathetic ministers and staff from agencies such as B.C.'s Ministry of Indigenous Relations and Reconciliation are sent to attend meetings and negotiations, often voicing support in principle for IPCAs; meanwhile, the ministries responsible for extractive resource industries continue to facilitate extraction on those same lands, in some instances regardless of Indigenous consent. As the former Chief of Yunesit'in Government explains:

[Sympathetic Ministers] don't have the power to do it. They can have the conversations internally and try to figure out what their laws are, but until they change their laws--namely legislation--and until they start tangibly formalizing consent and UNDRIP and have the willingness to engage in title and land reclamation for First Nations, I don't think much is going to materialize. (Chief Myers Ross, pers. comm., 2020) 
In the case of B.C., it also remains unclear how the provincial government's adoption of UNDRIP will be progressed from a symbolic statement of support to tangible implementation (CBC News, 2020; Province of B.C., 2021).

Where private companies hold government awarded tenures and licenses to extract resources or develop infrastructure (e.g. roads, rights of ways, urban and real estate developments) within the territories that comprise (or could comprise) an IPCA, these fundamentally different visions for the land are often in direct contradiction. The fiduciary and legal responsibilities that Crown agencies have to proponents and developers - as well as to Indigenous peoples - result in an inconsistent national approach to IPCAs. For example, where corporations hold mineral or forestry tenures in an area declared an IPCA by Indigenous governments, Crown agencies could face legal prosecution by the corporations involved if they prohibit extractive activities in support of the IPCA, unless they are able to purchase and retire the tenures (with public funds), which may be politically unpopular. Not surprisingly, then, not all IPCAs declared and established by Indigenous governments receive Crown recognition, support, or funding, while others, like Thaidene Nëné in the Northwest Territories, are tripartite partnerships founded in Indigenous and Crown legal orders. Industrial corporate interests can therefore influence government-to-government relationships, and thus the terms of CrownIndigenous reconciliation, by having a major (though largely unacknowledged) influence over which Indigenous governments receive government support for their initiatives and which ones are denied.

The unresolved mineral tenures were reportedly a significant contributing factor in Canada's decision not to fund Dasiqox-Nexwagwez?an (their application for federal Challenge Funds was unsuccessful). This happened despite the most significant mining development had been twice rejected by the federal government. Although Grassy Narrows' ISPA did receive federal Challenge Funds, securing ongoing funding opportunities, particularly from large NGOs and donors, is frustrated by the fact that Grassy's territory has been heavily impacted by resource extraction. A focus on meeting area-based conservation targets in a short time frame can lead to a prioritization of large, intact ecosystems, giving certain Indigenous Nations locational privilege $^{25}$ and discounting the importance of ecological restoration. Zurba et al. (2019) warn that treating IPCAs primarily as vehicles to meet Canada's conservation targets under the Convention on Biological Diversity risks undermining the importance of IPCAs for Indigenous communities and, by consequence, their biocultural conservation potential. They argue that it is important "to avoid a situation in which IPCAs become another, hopefully unintended, colonization of Indigenous peoples, their lands and biodiversity to meet Canada's Target 1 for protected areas" (p. 15). A focus on meeting targets alone means that Crown governments may step back from supporting Indigenous-led conservation once targets are met. For example, a 2020 freedom of information request revealed that some B.C. ministries stated they lacked a cabinet mandate to establish or increase IPCAs since B.C. had exceeded the 17\% terrestrial conservation target (Cox 2020). This sentiment reflects a "fleeting level of obligation to protect areas for Indigenous people, when [governments] feel they're already doing exceptionally well" (Myers Ross, pers. comm., 2021). This is why, we argue, IPCAs must be understood not merely as tools for area-based conservation, but as integral to Indigenous inherent, Aboriginal and Treaty rights to their lands and waters. Indigenous rights, including the rights to hunt, trap, and fish (including for commercial purposes) are contingent upon access to land and water that is healthful and generative. These rights become compromised when lands and waters are polluted or degraded by extractive or other industries.

As ICE argue in their report, "if Canada is willing to have conversations about jurisdiction with Indigenous Peoples across the country and actually give life back to the Treaties — sharing jurisdiction and responsibilities to and for the land - then the government will succeed in achieving [their international targets]" (ICE, 2018: 12). This responsibility must apply to all federal departments and ministries, and similarly to all those in the provinces and territories who have the jurisdiction to issue resource development licenses, permits and amendments, as the Supreme Court confirmed in the Grassy Narrows v. Ontario (Natural Resources) case in 2014. Being a signatory to UNDRIP, Crown agencies in Canada must meet their duty to con-

\footnotetext{
${ }^{25}$ For example, where Indigenous territories have high intact biodiversity value and where tourism benefits local municipalities, such as Tla-o-qui-aht Tribal Parks in Clayoquot Sound, B.C.
} 
sult and obtain free, prior and informed consent for all resource development projects that may affect Indigenous inherent, Aboriginal or Treaty rights. Indigenous communities, including Grassy Narrows and Tsilhqot'in, are "inadequately consulted or not consulted at all on amendments to licenses and tenures which are continuing to destroy the lands and waters" (M. Baptiste, pers. comm., 2020; see also Willow, 2012).

Given the challenges that Indigenous peoples have faced in attempting to forestall unwanted development using legal and regulatory channels, nations like Grassy Narrows, Xeni Gwet'in, and Yunesit'in have been proactively asserting their rights through IPCA establishment and on-the-ground political action. All of the First Nations discussed in this article have made headway in securing their territories from extractive capital by declaring IPCAs in concert with other strategies including direct action in the form of blockades, boycotting campaigns and other alliances with NGOs and environmentalists, and legal action. In the case of Dasiqox-Nexwagwez?an, the watershed title win in 2014 helped to further secure territorial sovereignty, though in a fragmented way (SCC 2014). Yet the threat of future extraction looms large as Canada and its provinces and territories continue to pursue a development strategy oriented around the extraction of nonrenewable resources (Bernauer and Roth, 2021; Peyton and Franks, 2016), and as some government agencies continue to mismanage or evade the issue of Indigenous jurisdiction. Thus, we have argued, Canada's conservation, reconciliation, and development policies are at odds, with the latter serving to undermine the prospect of reconciliation through conservation.

Decolonization is not a metaphor; rather, "decolonization brings about the repatriation of Indigenous land and life" (Tuck and Yang, 2012: 1) in order to rectify the "profound epistemic, ontological, [and] cosmological violence" (p. 5) of disrupting Indigenous relationships to their lands and waters. The cultural, spiritual, psychological, and material violence of disrupting these relationships cannot be overstated. Access to healthy and abundant lands and waters is imperative not only for food security and material sustenance, but also for cultural and spiritual vitality, the practice of ceremonies, language maintenance and revitalization, access to traditional medicines, and the intergenerational transfer of knowledge that is crucial to the maintenance of robust Indigenous knowledge systems (Big-Canoe and Richmond, 2014; Kassi, 2019). As Anishinabe scholar Leane Betasamosake Simpson explains, when the land is desecrated, so too are land-based Indigenous knowledge systems, as "Indigenous Knowledge must be lived" (Simpson, 2004: 381).

Research demonstrates that Indigenous communities have faced adverse health and social consequences from their removal or detachment from the land, including increased rates of substance abuse and youth suicide (Chandler et al., 2003; Chandler and Lalonde, 2004), and that spending more time on the land and water with community members decreases psychological stress, builds self-esteem and promotes a sense of self and cultural identity, all of which are associated with greater health and well-being (Kingsley et al., 2009; Kirmayer et al., 2000; Tobias and Richmond, 2016). As mechanisms that may facilitate Indigenous peoples' access to their ancestral lands and waters, support cultural revitalization, and act as sanctuaries of healing, IPCAs can be instruments of Indigenous resurgence and of reconciliation. If adequately recognized and supported by Crown agencies, IPCAs can help Canada atone for broken Treaty promises and uphold Indigenous peoples' inherent and constitutionally-enshrined rights to their lands and waters, breathe life into UNDRIP, and contribute to Canada's conservation targets in the spirit of reconciliation (Artelle et al., 2019).

\section{Conclusion}

Indigenous nations are increasingly declaring IPCAs throughout Canada to protect at least a portion of their lands and waters for future generations, as per their duties and responsibilities. This is happening along with Canada's interest in "counting" IPCAs towards its biodiversity conservation targets while advancing reconciliation. The result is a resurgence in Indigenous-led conservation (Artelle et al., 2019; Pathway to Canada Target 1, 2019; Zurba et al., 2019). While Crown government agencies are promoting and supporting IPCAs on the one hand (for example, through certain sympathetic Ministers and the federal government's Target 1 Challenge Fund and funding of Indigenous Guardians programs), they continue to uphold the hegemony of extractive capital in ways that directly threaten several IPCAs, as seen in the cases of Grassy Narrows' ISPA and Dasiqox-Nexwagweẑ?an. Government agencies granting mineral and forestry tenures and permits for exploration within IPCAs blatantly disrespects Indigenous rights, governance, and jurisdiction, and under- 
mines the biocultural conservation potential of IPCAs as well as their potential to facilitate reconciliation between the Crown and Indigenous peoples, and between all people and the lands and waters. Further, Indigenous governments struggling with unwanted and unresolved mineral tenures in their territories are at a disadvantage when seeking government funding for their conservation initiatives. Even Indigenous governments who have received federal funding, such as Grassy Narrows, have been forced to resort to on-the-ground direct action to defend their IPCAs from extractive capital. These contradictions highlight a disturbing paradox in Canadian conservation, whereby Indigenous-led conservation is supported in theory, but actively undermined in practice.

To the extent that many Indigenous economies have long embodied conviviality (Büscher and Fletcher, 2020; ICE, 2018), IPCAs are a novel tool in a longstanding fight to assert an alternative to settler capitalist hegemony. With its ambitious commitment to protect $30 \%$ of its land base by 2030 in the face of rampant climate change, unprecedented biodiversity loss, and the likelihood of future pandemics as a result of human encroachment on wildlife habitat (Jack et al., 2020), Canada would be prudent to prioritize Indigenous visions for IPCAs as viable alternatives to the colonial-capitalist accumulation paradigm at the root of environmental degradation. If Indigenous jurisdiction and visions for the lands and waters are upheld, IPCAs may offer glimpses into how alternative sustainabilities might work, including the possibility of IPCAs functioning as "reconciliation zones" (ICE 2018). Aligned with the national reconciliation agenda (TRC 2015), IPCAs could be prototypes for new relationships among settler society and Indigenous peoples, economies, and the biosphere.

To achieve such outcomes, further action is needed to address and resolve the multitude of drivers, stressors, challenges, and emerging and ongoing threats to the viability of IPCAs, and such action must be driven by Indigenous perspectives and governance. Further action is also warranted to develop and evolve efforts to decolonize existing state-led parks, using a multi-faceted approach that considers diverse options and outcomes, while prioritizing biocultural conservation and reconciliation (ICE, 2018). Importantly, however, "Indigenous-led conservation initiatives will be limited in their ability to challenge extractivism on their own" (Bernauer and Roth, 2021: 216), and thus the conservation revolution must be part of a much broader movement for total human and non-human liberation from the interconnected systems of oppression undergirding the global biodiversity crisis, including colonialism and white supremacy, patriarchy, and capitalism, among others. If the teachings of IPCAs can be appreciated and applied well beyond their borders, they will be invaluable in building a transformative, convivial future.

\section{Bibliography}

Agrawal, A., \& Redford, K. (2009). Conservation and displacement: An overview. Conservation and Society, 7(1), 1-10.

Armitage, D. (2002). Socio-institutional dynamics and the political ecology of mangrove forest conservation in Central Sulawesi, Indonesia. Global Environmental Change, 12, 203-217.

Artelle, K. A., Zurba, M., Bhattacharrya, J., Chan, D. E., Brown, K., Housty, J., \& Moola, F. (2019). Supporting resurgent Indigenous-led governance: A nascent mechanism for just and effective conservation. Biological Conservation, 240, 1-10.

Asch, M. (1984). Home and native land: Aboriginal Rights and the Canadian Constitution. Methuen.

Barkwell, L. (2005). Batoche 1885: The militia of the Métis Liberation Movement. Manitoba Métis Federation.

Barrera, J. (2003). Grassy band throws up another blockade. Kenora Daily Miner and News.

Barrera, J. (2020). Six Nations members expand road blockades around land reclamation camp in Caledonia, Ont. CBC News. Available at: https://www.cbc.ca/news/indigenous/six-nations-caledonia-land-backlane-1.5774581

Bella, L. (1986). Parks for profit. Harvest House. 
Bellrichard, C. (2019). Hereditary chiefs in B.C. stand opposed to Coastal GasLink pipeline despite injunction. CBC News. Available at: https://www.cbc.ca/news/indigenous/hereditary-chiefs-in-b-c-standopposed-to-coastal-gaslink-pipeline-despite-injunction-1.4968169

Benzie, R. (2021). Tories slammed for allowing gold mining claims in Grassy Narrows as mercury cleanup stalls. Toronto Star. Available at: https://www.thestar.com/politics/provincial/2021/04/13/toriesaccused-of-allowing-gold-mining-claims-in-grassy-narrows-as-mercury-cleanup-stalls.html

Bernauer, W., \& Roth, R. (2021). Protected areas and extractive hegemony: A case study of marine protected areas in the Qikiqtani (Baffin Island) region of Nunuvut, Canada. Geoforum, 120, 208-217.

Bhattacharyya, J., Murray, M., Whittaker, C., \& Firelight Group. (2018). Nexwagweẑ?an community vision and management goals for Dasiqox Tribal Park. Prepared for the Yunesit'in First Nation, Xeni Gwet'in First Nation, and Dasiqox Tribal Park Planning Team.

Big-Canoe, K., \& Richmond, C. A. M. (2014). Anishinabe youth perceptions about community health: toward environmental repossession. Health \& Place, 26, 127-135.

Bill 41. (2019). Declaration on the Rights of Indigenous Peoples Act, 2019. Available at: https://www.leg.bc.ca:443/parliamentary-business/legislation-debates-proceedings/41stparliament/4th-session/bills/first-reading/gov41-1

Binnema, T. T., \& Niemi, M. (2006). 'Let the Line Be Drawn Now': Wilderness, conservation, and the exclusion of Aboriginal People from Banff National Park. Environmental History, 11(4), 724-750.

Borrows, J. (2010). Canada's Indigenous Constitution. University of Toronto Press.

Borrows, J. (2015). The durability of terra nullius: Tsilhqot'in Nation v British Columbia. UBC Law Review, 48(3), 701-742.

Brockington, D., \& Igoe, J. (2006). Eviction for conservation: A global overview. Conservation and Society, 4(3), 424-470.

Bruser, D. (2020). Declaring sovereignty over land, Grassy Narrows First Nation leaders ban clear-cut logging. The Toronto Star. Available at: https://www.thestar.com/news/investigations/2018/10/10/declaring-sovereignty-over-land-grassynarrows-fn-leaders-ban-clear-cut-logging.html

Büscher, B., \& Davidov, V. (Eds.) (2013). The ecotourism-extraction nexus: Political economies and rural realities of (un)comfortable bedfellows. Routledge.

Büscher, B., \& Fletcher, R. (2019). Towards convivial conservation. Conservation and Society, 17(3), 283296.

Büscher, B., \& Fletcher, R. (2020). The Conservation Revolution: Radical ideas for saving nature beyond the Anthropocene. Verso.

Canada National Parks Act (S.C., 2000, c. 32). Available at: https://laws-lois.justice.gc.ca/eng/acts/N-14.01/

Campbell, C. (2011). A century of Parks Canada 1911-2011. University of Calgary Press.

Canadian Parks and Wilderness Society (CPAWS). (2012). The State of Canada's Parks: 2012 Report. Available at: https://cpaws.org/wp-content/uploads/2019/07/cpaws_parksreport_2012.pdf

Cavanagh, C., (2017). Political ecology, variegated green economies, and the foreclosure of alternative sustainabilities. Journal of Political Ecology, 24(1), 200-216. https://doi.org/10.2458/v24i1.20800

Carroll, C. (2014). Native enclosures: Tribal national parks and the progressive politics of environmental stewardship in Indian Country. Geoforum, 53, 31-40. https://doi.org/10.1016/j.geoforum.2014.02.003

CBC News. (2020). It's time for the B.C. NDP to get serious about UNDRIP, Indigenous leaders say. Available at: https://www.cbc.ca/news/canada/british-columbia/indigenous-leaders-reaction-1.5777509

CBC News. (2014). Gros Morne oil fracking plan leads UNESCO to seek buffer zone. Available at: https://tinyurl.com/2rdvcthb

Chandler, M., Lalonde, C., Sokol, B., \& Hallet, D. (2003). Personal persistence, identity development, and suicide: a study of Native and Non-native North American adolescents. Monographs of the Society for Research in Child Development, 68(2), 131-138. https://doi.org/10.1111/1540-5834.00246 
Chandler, M., \& Lalonde, C. (2004). Cultural continuity as a moderator of suicide risk among Canada's First Nations. In Kirmayer, L., \& Valaskakis, G. (Eds.), Healing traditions: The mental health of Aboriginal peoples in Canada. University of British Columbia Press.

Chatty, D., \& Colchester, M. (2002). Conservation and mobile indigenous peoples: Displacement, forced settlement, and sustainable development. Berghahn Books.

Coburn, E., \& LaRocque, E. (2015). More will sing their way to freedom: Indigenous resistance and resurgence. Fernwood Publishing.

Conservation Through Reconciliation Partnership (CRP). (n.d.). Conservation through reconciliation. Available at: https://conservation-reconciliation.ca/

Coulthard, G. (2014). Red skin, white masks: Rejecting the colonial politics of recognition. University of Minnesota Press.

Cox, S. (2020). 'No mandate' from B.C. government for new protected areas: FOI docs. The Narwhal. Available at: https://thenarwhal.ca/bc-government-kaska-indigenous-protected-area-foi/

Cronon, W. (1996). Uncommon ground: Rethinking the human place in nature. W.W. Norton \& Co.

Daschuk, J. (2013). Clearing the plains: Disease, politics of starvation, and the loss of Aboriginal Life. University of Regina Press.

Dasiqox Tribal Park Initiative. (2020). Dasiqox Tribal Park. Available at: https://asiqox.org/

Dasiqox Tribal Park Initiative. (2021). Map. Available at: https://dasiqox.org/about-us/map/

David Suzuki Foundation (DSF). (2021). Tell the government to respect Indigenous land rights. Available at: https://davidsuzuki.org/action/stand-with-grassy-narrows/

Davis, H., \& Todd, Z. (2017). On the importance of a date, or, decolonizing the Anthropocene. ACME: An International Journal for Critical Geographies, 16(4), 761-780.

Dowie, M. (2009). Conservation refugees: The hundred-year conflict between global conservation and native peoples. MIT Press.

Drawson, A.S., Toombs, E., \& Mushquash, C.J. (2017). Indigenous research methods: A systematic review. International Indigenous Policy Journal, 8(2), 1-25. https://doi.org/10.18584/iipj.2017.8.2.5

Enns, C., Bersaglio, B., \& Sneyd, A. (2019). Fixing extraction through conservation: On crises, fixes and the production of shared value and threat. Environment and Planning E: Nature and Space, 2(4), 967-988. https://doi.org/10.1177\%2F2514848619867615

Erikson, K. \& Vecsey, C. (1980). A Report to the People of Grassy Narrows. Vecsey C. \& Venables, R.W. (Eds.). American Indian environments. (pp. 152-161). Syracuse University Press.

Estes, N. (2019). Our history is the future: Standing Rock versus the Dakota Access Pipeline, and the long history of Indigenous resistance. Verso.

Fletcher, R. \& Büscher, B. (2020). Conservation basic income: A non-market mechanism to support convivial conservation. Biological Conservation, 244, 1085210.

Fletcher, R., Büscher, B., Massarella, K., \& Koot, S. (2020). 'Close the Tap!': COVID-19 and the need for Convivial Conservation. Journal of Australian Political Economy, 85, 200-211.

FreeGrassy, (2015). Grassy Narrows looking to take case to Supreme Court. Available at: https://freegrassy.net/grassy-narrows-looking-to-take-case-to-supreme-court/

FreeGrassy, (2018). Grassy Narrows land declaration bans all industrial logging. Available at: https://freegrassy.net/grassy-narrows-land-declaration-bans-all-industrial-logging/

FreeGrassy, (2021). Virtual campaign launch. Available at: https://freegrassy.net/compensation-for-allvirtual-campaign-launch/

Gilpin, E. (2020). COVID-19 not the first pandemic Indigenous Peoples have quarantined from. National Observer. Available at: https://www.nationalobserver.com/2020/04/02/news/covid-19-not-firstpandemic-indigenous-peoples-have-quarantined 
Gorrie, P. (2008). Protest prompts Abitibi pullout. Toronto Star. Available at: https://www.thestar.com/business/tech_news/2008/06/05/protest_prompts_abitibi_pullout.html

Government of Canada, (2018). News release: Government of Canada puts \$175 million toward projects that protect nature. Available at: https://www.canada.ca/en/environment-climatechange/news/2018/12/government-of-canada-puts-175-million-toward-projects-that-protectnature.html

Government of Canada. (2019). Canada, British Columbia, and the Tŝilhqot'in Nation Sign Gwets'en Nilt'i Pathway Agreement [News releases]. Available at: https://www.canada.ca/en/crown-indigenousrelations-northern-affairs/news/2019/08/canada-british-columbia-and-the-tsilhqotin-nation-signgwetsen-nilti-pathway-agreement.html

Government of Canada, (2020). Indigenous Guardians Pilot Program map. Available at: https://www.canada.ca/en/environment-climate-change/services/environmental-funding/indigenousguardians-pilot-program/map.html

Government of Canada, (2020b). How does the forest industry contribute to Canada's economy? Available at: https://www.nrcan.gc.ca/our-natural-resources/forests-forestry/state-canadas-forests-report/forestindustry-contribute/16517

Government of Canada, (2020c). Indicator: Gross Domestic Product. Available at: https://www.nrcan.gc.ca/our-natural-resources/forests-forestry/state-canadas-forests-report/how-doesforest-sector-contribut/indicator-gross-domestic-product/16556

Government of Canada. (2020d). Backgrounder: Bill C-15 - United Nations Declaration on the Rights of Indigenous Peoples Act. Available at: https://www.justice.gc.ca/eng/declaration/about-apropos.html

Grassy Narrows First Nation v. Ontario (Natural Resources), (2014). SCC 48 (CanLII), [2014] 2 SCR 447. Available at: http://canlii.ca/t/g80bn

Harada, M., Hanada, M., Miyakita, T., Fujino, T., Tsuruta, K., Fukuhara, A., Orui, T., Nakachi, S., Araki, C., Tajiri, M. \& Nagano, I. (2005). Long-term study on the effects of mercury contamination on two indigenous communities in Canada (1975-2004). Research on Environmental Disruption, 34(4), 1-11.

Holmes, G. \& Cavanagh, C. (2016). A review of the social impacts of neoliberal conservation: Formations, inequalities, contestations. Geoforum, 75, 199-209.

Hoogeveen, D. (2015). Sub-surface property, free-entry mineral staking and settler colonialism in Canada. Antipode, 47(1), 121-138. https://doi.org/10.1111/anti.12095

ICCA Consortium. (n.d.). ICCAs. Available at: https://www.iccaconsortium.org/

Ilyniak, N. (2014). Mercury poisoning in Grassy Narrows: Environmental injustice, colonialism, and capitalist expansion in Canada. McGill Sociological Review, 4, 43-66.

Impact Assessment Agency of Canada. (2017a). From Canadian Environmental Assessment Agency to Taseko Mines Limited re: Application of the s.6 prohibition under the Canadian Environmental Assessment Act, 2012. https://iaac-aeic.gc.ca/050/evaluations/document/119843

Impact Assessment Agency of Canada. (2017b). Backgrounder: Proposed new Prosperity Gold-Copper Mine Project. Canadian Impact Assessment Registry. https://ceaa.gc.ca/050/evaluations/document/98460?culture=en-CA

Impact Assessment Agency of Canada. (2020). New Prosperity Gold-Copper Mine Project. https://iaacaeic.gc.ca/050/evaluations/proj/63928?culture=en-CA

Indigenous and Northern Affairs Canada. (2020a). Registered population: Xeni Gwet'in First Nations Government [Administrative page; home page]. First Nation Profiles. https://fnp-ppn.aadncaandc.gc.ca/fnp/Main/Search/FNRegPopulation.aspx?BAND_NUMBER=714\&lang=eng

Indigenous and Northern Affairs Canada. (2020b). Registered population: Yunesit'in Government. First Nation Profiles. https://fnp-ppn.aadncaandc.gc.ca/fnp/Main/Search/FNRegPopulation.aspx?BAND_NUMBER=717\&lang=eng 
Indigenous Circle of Experts (ICE). (2018). We rise together: Achieving pathway to Canada Target 1 through the creation of Indigenous Protected and Conserved Areas in the spirit of practice of reconciliation. The Indigenous Circle of Experts' Report and Recommendations. Available at: http://www.conservation2020canada.ca/

IPBES. (2019): Summary for policymakers of the global assessment report on biodiversity and ecosystem services of the Intergovernmental Science-Policy Platform on Biodiversity and Ecosystem Services. S. Díaz, S. et al. (Eds.). IPBES secretariat, Bonn. https://doi.org/10.5281/zenodo.3553579

IPCC. (2019). Summary for Policy Makers. An IPCC Special Report on climate change, desertification, land degradation, sustainable land management, food security, and greenhouse gas fluxes in terrestrial ecosystems. (pp 1- 41). In Climate change and land. WMO and UNEP. Bonn.

IUCN. (2020). World Heritage Outlook: Wood Buffalo National Park. Available at: https://worldheritageoutlook.iucn.org/explore-sites/wdpaid/10902

Jack, J., Gonet, J., Mease, A., \& Nowak, K. (2020). Traditional Knowledge underlies One Health. Science 369(6511), 1576. https://doi.org/10.1126/science.abe2401

Kassi, N. (2019). An Indigenous perspective on protecting the Canadian boreal zone 1. Environmental Reviews, 27(3), 422-423. https://doi.org/10.1139/er-2018-0093@er-bor.issue01

Keewatin v. Ontario (Natural Resources). (2013). ONCA 158 (CanLII). Available at: http://canlii.ca/t/fwjp2

Kingsley, J., Townsend, M., Phillips, R., \& Aldous, D. (2009). "If the land is healthy ... it makes the people healthy": The relationship between caring for Country and health for the Yorta Yorta Nation, Boonwurrung and Bangerang Tribes. Health \& Place, 15(1), 291-299.

Kirmayer, L., Brass, G., \& Tait, C. (2000). The mental health of Aboriginal Peoples: Transformations of identity and community. The Canadian Journal of Psychiatry, 45(7), 607-616.

Kovach, M. (2009). Indigenous methodologies: Characteristics, conversations, and contexts. University of Toronto Press.

Lemieux, C., Beechey, T., \& Gray, P. (2011). Prospects for Canada's protected areas in an era of rapid climate change. Land Use Policy, 28(4), 928-941.

Lavoie, J. (2017). British Columbians saddled with $\$ 40$ Million clean-up bill as Imperial Metals escapes criminal charges. The Narwhal. Available at: https://thenarwhal.ca/british-columbians-saddled-40-millionclean-bill-imperial-metals-escapes-criminal-charges/

Lavoie, J. (2019a). 'This is not Canada': Inside the Tsilhqot'in Nation's battle against Taseko Mines. The Narwhal. Available at: https://thenarwhal.ca/this-is-not-canada-inside-the-tsilhqotin-nations-battle-againsttaseko-mines/

Lavoie, J. (2019b). 'When are they going to ensure the polluter pays?': Proposed B.C. mining reforms don't go far enough. The Narwhal. Available at: https://thenarwhal.ca/when-are-they-going-to-ensure-thepolluter-pays-proposed-b-c-mining-reforms-dont-go-far-enough/

Lavoie, J. (2020). Taseko's loss in Supreme Court may not be the end of embattled New Prosperity mine, Tsilhqot'in warn. The Narwhal. Available at: https://thenarwhal.ca/tasekos-loss-supreme-courtembattled-new-prosperity-mine-tsilhqotin-warn/

Leslie, K. (2016). 90\% of Grassy Narrows residents show mercury poisoning signs: Researchers. The Globe and Mail. Available at: https://www.theglobeandmail.com/news/national/90-of-grassy-narrowsresidents-show-mercury-poisoning-signs-researchers/article31966087/

Linnitt, C. (2020). A timeline from birth to death of Taseko's embattled New Prosperity mine in B.C. The Narwhal. Available at: https://thenarwhal.ca/timeline-birth-to-death-tasekos-embattled-newprosperity-mine-bc/

Linnitt, C. (2017). Outgoing B.C. Liberals issue mining permits in Tsilhqot'in Territory during wildfire evacuation. The Narwhal. Available at: https://thenarwhal.ca/outgoing-b-c-liberals-issue-mining-permitstsilhqot-territory-during-wildfire-evacuation/ 
Linnitt, C. (2014). Bill 4 Passes: B.C. Parks now officially open to pipelines and drilling. The Narwhal. Available at: https://thenarwhal.ca/bill-4-passes-b-c-parks-now-officially-open-pipelines-and-drilling/

Loo, T. (2001). Making a modern wilderness: Conserving wildlife in twentieth-century Canada. The Canadian Historical Review, 82(1), 91-121.

Lunstrum, E. (2016). Green grabs, land grabs and the spatiality of displacement: eviction from Mozambique's Limpopo National Park. Area, 48(2), 142-152.

Mabee, H. S., \& Hoberg, G. (2006). Equal partners? Assessing comanagement of forest resources in Clayoquot Sound. Society and Natural Resources, 19(10), 875-888.

MacLaren, I. (2007). Culturing wilderness in Jasper National Park: Studies in two centuries of human history in the Upper Athabasca River Watershed. University of Alberta Press.

Manuel, A., \& Derrickson, Grand Chief R. M. (2015). Unsettling Canada. Between the Lines.

McDermott, L., \& Wilson, P. (2010). 'Ginawaydaganuk': Algonquin Law on Access and Benefit Sharing. IUCN Policy Matters. Available at: https://www.iucn.org/downloads/policy_matters_17_pg_205_241.pdf

McGregor, D. (2018). Mino-Mnaamodzawin. Environment and Society, 9(1), 7-24.

McIvor, B. (2014). Provinces burdened with responsibility for fulfilling Treaty promises: Grassy Narrows First Nation v. Ontario (Natural Resources), 2014 SCC 48 (CanLII). CanLII Connects. Available at: https://www.canliiconnects.org/en/summaries/28319

Middleton, B. R. (2015). Jahát Jat'totòdom: Toward an indigenous political ecology. In Bryant. R. (Ed..), The International Handbook of Political Ecology (pp. 561-576). Edward Elgar.

Miller, J.R. (2009). Compact, Contract, Covenant: Aboriginal treaty-making in Canada. University of Toronto Press.

Mining Association of Canada. (2020). Facts \& figures: The state of Canada's mining industry. Available at: https://mining.ca/wp-content/uploads/2021/02/FF-2020-EN-Web-1.pdf

Mittelstaedt, M. (2000). Abitibi sued over N. Ontario logging. Toronto Globe and Mail. Available at: https://www.theglobeandmail.com/report-on-business/abitibi-sued-over-n-ontariologging/article4162450/

Moola, F., \& Roth, R. (2019). Moving beyond colonial conservation models: Indigenous Protected and Conserved Areas offer hope for biodiversity and reconciliation in Canada's boreal forest. Environmental Review, 27(2), 200-201.

Moore, A. (2020). Sipekne'katik First Nation refuses to negotiate away treaties, calls off talks with Canada. APTN National News. Available at: https://www.aptnnews.ca/national-news/sipeknekatik-first-nationrefuses-to-negotiate-away-treaties-calls-off-talks-with-canada/

Mulrennan, M.E., Mark, R. \& Scott, C.H. (2012). Revamping community-based conservation through participatory research. The Canadian Geographer/ Le Géographe canadien, 56, 243-259.

Murray, G., \& King, L. (2012). First Nations values in protected area governance: Tla-o-qui-aht parks and Pacific Rim National Park Reserve. Human Ecology, 40, 385-395.

National Advisory Panel (NAP). (2018). Canada's conservation vision: A report of the National Advisory Panel. Available https://static1.squarespace.com/static/57e007452e69cf9a7af0a033/t/5b23dce1562fa7bac7ea095a/1529 076973600/NAP_REPORT_EN_June+5_ACC.pdf

Nemiah Valley Indian Band. (1989). Nenduwh Jid Guzitin Declaration. Available at: https://www.fonv.ca/nemaiahvalley/nenduwhjidguzitindeclaration/

Pathway to Canada Target 1. (2019). The pathway. Available at: https://www.conservation2020canada.ca/thepathway

Neumann, R. (1992). Political ecology of wildlife conservation in the Mt. Meru area of Northeast Tanzania. Land Degradation \& Rehabilitation, 3, 85-98. 
Neumann, R. (1998). Imposing wilderness: Struggles over livelihood and nature preservation in Africa. University of California Press.

Neumann, R. (2005). Making political ecology. Hodder Arnold.

Norman, E. S. (2017). Standing up for inherent rights: The role of Indigenous-Led activism in protecting sacred waters and ways of life. Society \& Natural Resources, 30(4), 537-553.

Norris, T. (2017). Shared social license: Mining and conservation in the Peruvian Andes. Antipode, 49(3), 721-741.

Office of the Auditor General of Canada, (2013). 2013 Fall Report of the Commissioner of the Environment and Sustainable Development: Chapter 7 - Ecological integrity in National Parks. Available at: https://www.oag-bvg.gc.ca/internet/English/parl_cesd_201311_07_e_38677.html\#ex1

Parks Canada. (2019). Science and conservation: Stressors. Available at: https://www.pc.gc.ca/en/nature/science/conservation/stress-stressors

Pasternak, S., Collins, S., \& Dafnos, T. (2013). Criminalization at Tyendinaga: securing Canada's colonial property regime through specific land claims. Canadian Journal of Law and Society, 28(1), 65-81. https://doi.org/10.1017/cls.2013.4

Peet, R., Robbins, P., \& Watts, M.J., (2011). Introduction: Global nature. In Peet, R., Robbins, P., \& Watts, M.J. (Eds.) Global Political Ecology. (pp. 1-48). Routledge.

Persaud, A. W. (2020). Counter-institutionalization and the economic futures of First Nations in British Columbia. $\quad \mathrm{PhD} \quad$ Dissertation. University of British Columbia. https://open.library.ubc.ca/cIRcle/collections/ubctheses/24/items/1.0395409

Peyton, J. \& Franks, A. (2016). The new nature of things? Canada's Conservative government and the design of the new environmental subject. Antipode, 48, 453-473.

Philibert, A., Fillion, M., \& Mergler, D. (2020). Mercury exposure and premature mortality in the Grassy Narrows First Nation community: a retrospective longitudinal study. The Lancet: Planetary Health, 4(4), E141-E148. https://doi.org/10.1016/S2542-5196(20)30057-7

Province of B.C. (2021). B.C. Declaration on the Rights of Indigenous Peoples Act. Province of British Columbia. Available at: https://www2.gov.bc.ca/gov/content/governments/indigenous-people/newrelationship/united-nations-declaration-on-the-rights-of-indigenous-peoples

Province of British Columbia. (n.d.). Mineral Titles Online. Available at: https://www.mtonline.gov.bc.ca/mtov/home.do

Rainforest Action Network (RAN). (2008). Grassy Narrows wins. For real. The Rainforest Action Network Blog. Available at: https://www.ran.org/the-understory/grassy_narrows_wins_for_real/

Roth, R. (2008). "Fixing" the forest: The spatiality of conservation conflict in Thailand. Annals of the Association of American Geographers, 98(2), 373-391.

Sandlos, J. (2008). Not wanted in the boundary: The expulsion of the Keeseekoowenin Ojibway Band from Riding Mountain National Park. Canadian Historical Review, 89(2), 189-221.

Sandlos, J. (2014). National Parks in the Canadian north: Comanagement or colonialism revisited? Indigenous peoples, national parks, and protected areas. In S. Stevens (ed.), Indigenous Peoples, National Parks, and Protected Areas. (pp. 133-149). University of Arizona Press.

SCC 44. (2014). Tsilhqot'in Nation v. British Columbia. 2 S.C.R. 256. Available at: https://scccsc.lexum.com/scc-csc/scc-csc/en/item/14246/index.do

Schulz, K. A. (2017). Decolonizing political ecology: Ontology, technology and "critical" enchantment. Journal of Political Ecology, 24(1), 125-143. https://doi.org/10.2458/v24i1.20789

Schuster, R., Germain, R. R., Bennett, J. R., Reo, N. J., \& Arcese, P. (2019). Vertebrate biodiversity on indigenous-managed lands in Australia, Brazil, and Canada equals that in protected areas. Environmental Science \& Policy, 101, 1-6._https://doi.org/10.1016/j.envsci.2019.07.002

Seagle, C. (2012). Inverting the impacts: mining, conservation and sustainability claims near the Rio Tinto/QMM ilmenite mine in Southeast Madagascar. Journal of Peasant Studies, 39(2), 447-477. 
Simpson, L. (2004). Anticolonial strategies for the recovery and maintenance of indigenous knowledge. American Indian Quarterly, 28(3/4), 373-384.

Singh, S., Bursey, D., Teal, C., \& Curpen, R. (2019). British Columbia's UNDRIP legislation-A framework to advance reconciliation. The Canadian Bar Association. Available at: https://www.cba.org/Sections/Business-Law/Articles/2019/UNDRIP

Smith, L. T. (1999). Decolonizing methodologies: Research and Indigenous peoples. Zed.

Smith R., Cannizzo Z. J., Belle E., \& Wenzel L. (2020). Role of Protected Areas in climate change mitigation, adaptation and disaster risk reduction. In Leal Filho W., Azul A., Brandli L., Özuyar, P.G., \& Wall, T. (Eds.) Climate action encyclopedia of the UN Sustainable Development Goals. Springer.

Snow, Chief J. (1977). These Mountains are our Sacred Places: The story of the Stoney People. Fifth House Publishers.

Spice, A. (2018). Fighting invasive infrastructures, Environment and Society, 9(1), 40-56.

Stacey, J., Verhaeghe, C., \& Feltes, E. (2019). NAGWEDIẐK'AN GWANEŜS GANGU CH'INIDẐED GANEXWILAGH: The fires awakened us: Tsilhqot'in report on the 2017 wildfires. Available at: https://commons.allard.ubc.ca/fac_pubs/606/

Stevens, S. (ed.) (2014). Indigenous Peoples, National Parks, and Protected Areas: A new paradigm linking conservation, culture, and rights. University of Arizona Press.

Sullivan, S. (2017). What's ontology got to do with it? On nature and knowledge in a political ecology of the 'green economy'. Journal of Political Ecology, 24(1), 217-242. https://oi.org/10.2458/v24i1.20802

Thom, B. (2001). Aboriginal Rights and title in Canada After Delgamuukw: Part One, oral traditions and anthropological evidence in the courtroom. Native Studies Review, 14(1), 1-26.

Tiny House Warriors. (2020). Our Land is Our Home. Available at: http://www.tinyhousewarriors.com/

Tobias, J., \& Richmond C. (2014). "That land means everything to us as Anishinaabe....": Environmental dispossession and resilience on the North Shore of Lake Superior. Health \& Place, 29, 26-33. https://doi.org/10.1016/j.healthplace.2014.05.008

Townsend, J., Youdelis, M., \& Moola, F. (2019). Tsilhqot'in blockade points to failures of justice impeding reconciliation in Canada. The Conversation. Available at: https://theconversation.com/tsilhqotinblockade-points-to-failures-of-justice-impeding-reconciliation-in-canada-120488

Tran, T. C., Ban, N. C., \& Bhattacharyya, J. (2020). A review of successes, challenges, and lessons from Indigenous protected and conserved areas. Biological Conservation, 241, 108271. https://doi.org/10.1016/j.biocon.2019.108271

Troyer, W. (1977). No safe place. Clarke, Irwin, and Company.

TRC. (2015). Honouring the truth, reconciling for the future: Summary of the Final Report of the Truth and Reconciliation Commission of Canada. Available at: www.trc.ca

Tsilhqot'in Nation, Canada, \& British Columbia. (2019). Gwets'en Nitlt'i Pathway Agreement.

Tsilhqot'in Nation v. British Columbia. (2014). No. 34986, SCC June 26, 2014. Available at: https://scccsc.lexum.com/scc-csc/scc-csc/en/item/14246/index.do

Tŝilhqot'in National Government. (2020). Communities. Available at: https://www.tsilhqotin.ca/communities/

Tuck, E., \& Yang, K. W. (2012). Decolonization is not a metaphor. Decolonization: Indigeneity, Education \& Society, 1(1), 1-40.

UN General Assembly. (2008). United Nations Declaration on the Rights of Indigenous Peoples: Resolution/adopted by the General Assembly. Resolution 61/295. Available at: https://doi.org/10.1093/iclqaj/24.3.577

Unist'ot'en. (2017). Wet'suwet'en Hereditary Chiefs evict coastal gaslink from territory. Unist'ot'en Camp Blog. Available at: https://unistoten.camp/wetsuweten-hereditary-chiefs-evict-coastal-gaslink-fromterritory/

Vandergeest, P., \& Peluso, N. (1995). Territorialization and state power in Thailand. Theory and Society, 24(3), 385-426. 
Vecsey, C. (1987). Grassy Narrows Reserve: mercury pollution, social disruption, and natural resources: a question of autonomy. American Indian Quarterly, 11(4), 287-314.

Wang, S. (2021). Ontario promised to get to the bottom of alleged mercury dumps upstream from Grassy Narrows. Instead, the province allowed a surge in mining claims on the Indigenous territory. The Toronto Star. Available at: https://www.thestar.com/news/investigations/2021/04/12/ontario-promised-to-getto-the-bottom-of-alleged-mercury-dumps-upstream-from-grassy-narrows-instead-the-provinceallowed-a-surge-in-mining-claims-on-the-indigenous-territory.html

Watkins, M. (1977). Dene Nation: The colony within. University of Toronto Press.

Weber, B. (2017). Canada's biggest national park among most threatened: international scientists. National Post. Available at: https://nationalpost.com/pmn/news-pmn/canada-news-pmn/international-scientistsraise-alarm-about-wood-buffalo-world-heritage-site

Welsh, M., \& Bruser, D. (2020). Grassy Narrows First Nation fears further mercury poisoning as Ford government ends assessments for clear-cut logging. Toronto Star. Available at: https://www.thestar.com/news/canada/2020/07/10/the-end-of-environmental-assessments-for-clearcut-logging-has-grassy-narrows-first-nation-fearing-more-mercury-poisoning.html

West, P. (2006). Conservation is our government now: The politics of ecology in Papua New Guinea. Durham: Duke University Press.

West, P., Igoe, J., \& Brockington, D. (2006). Parks and peoples: The social impact of protected areas. Annual Review of Anthropology, 35, 251-277. https://doi.org/10.1146/annurev.anthro.35.081705.123308

West, P. \& Aini, J. (2018). Critical approaches to dispossession in the Melanesian Pacific: Conservation, voice, and collaboration. Keynote Lecture, POLLEN 2018 Political Ecology Network Biennial Conference, 19 - 22 June, Oslo, Norway.

Willow, A. (2012). Strong hearts, Native lands: Anti-clearcutting activism at Grassy Narrows First Nation. University of Manitoba Press.

Wilson, S. (2008). Research is ceremony: Indigenous research methods. Fernwood Publishing.

Woodward \& Company. (n.d.). Blazing a trail for reconciliation, self-determination \& decolonization: Tsilhqot'in Nation v. British Columbia and Canada. Available at: https://www.woodwardandcompany.com/tsilhqotin/

World Resource Institute (WRI). (2003). Mining and critical ecosystems: Mapping the risks. Washington: WRI.

Yellowhead Institute. (2019). Land back: A Yellowhead Institute Red Paper. Available at: https://redpaper.yellowheadinstitute.org/wp-content/uploads/2019/10/red-paper-report-final.pdf

Youdelis, M. (2016). "They could take you out for coffee and call it consultation!": The colonial antipolitics of Indigenous consultation in Jasper National Park. Environment and Planning A, 48(7), 1374-1392. https://doi.org/10.1177\%2F0308518X16640530

Youdelis, M., Nakoochee, R., O'Neil, C., Lunstrum, E. \& Roth, R. (2020). "Wilderness" revisited: Is Canadian park management moving beyond the "wilderness" ethic? The Canadian Geographer / Le Géographe canadien, 64, 232-249. https://doi.org/10.1111/cag.12600

Zalik, A. (2011). Protest-as-violence in Oil Fields: The contested representation of profiteering in two extractive sites. In Feldman, S., Geisler, C., \& Menon, G.A. (Eds.) Accumulating insecurity: Violence and dispossession in the making of everyday life. (pp. 261-284). University of Georgia Press.

Zurba, M., Beazley, K., English, E., \& Buchmann-Duck, J. (2019). Indigenous Protected and Conserved Areas (IPCAs), Aichi Target 11 and Canada's Pathway to Target 1: Focusing conservation on reconciliation. Land, 8(10), 1-20. https://doi.org/10.3390/land8010010 